medRxiv preprint doi: https://doi.org/10.1101/2021.07.16.21260601; this version posted July 20, 2021. The copyright holder for this preprint (which was not certified by peer review) is the author/funder, who has granted medRxiv a license to display the preprint in perpetuity. It is made available under a CC-BY-NC-ND 4.0 International license .

\title{
Multi-Omic Analyses Characterize the Ceramide/Sphingomyelin Pathway as a Therapeutic Target in Alzheimer's Disease
}

Priyanka Baloni ${ }^{1 *}$, Matthias Arnold ${ }^{2,6 *}$, Herman Moreno ${ }^{3 *}, K_{\text {wangsik Nho }}^{4 *}$, Luna Buitrago $^{3}$, Kevin Huynh ${ }^{5}$, Barbara Brauner ${ }^{2}$, Gregory Louie ${ }^{6}$, Alexandra KueiderPaisley $^{6}$, Karsten Suhre ${ }^{7}$, Andrew J. Saykin ${ }^{4}$, Kim Ekroos ${ }^{8}$, Peter J. Meikle ${ }^{5}$, Leroy Hood $^{1}$, Nathan D. Price ${ }^{1}$, The Alzheimer's disease Metabolomics Consortium, P. Murali Doraiswamy $^{6}$, Cory C. Funk ${ }^{1}$, Gabi Kastenmüller ${ }^{2}$, Rebecca Baillie ${ }^{9}$, Xianlin Han ${ }^{10 \ddagger}$ and Rima Kaddurah-Daouk ${ }^{6,11,12 \ddagger}$

* Equal contribution

‡ Corresponding author

\section{Author's affiliations}

${ }^{1}$ Institute for Systems Biology, Seattle, WA, USA

2 Institute of Computational Biology, Helmholtz Zentrum München - German Research Center for Environmental Health, Neuherberg, Germany

${ }^{3}$ Department of Neurology/Pharmacology, SUNY Downstate Medical Center, Brooklyn, NY, USA

${ }^{4}$ Indiana Alzheimer Disease Center and Department of Radiology and Imaging Sciences, Indiana University School of Medicine, Indianapolis, IN, USA

${ }^{5}$ Metabolomics Laboratory, Baker Heart and Diabetes Institute, Melbourne, VIC, Australia

${ }^{6}$ Department of Psychiatry and Behavioral Sciences, Duke University School of Medicine, Durham, Durham, NC, USA.

${ }^{7}$ Department of Physiology and Biophysics, Weill Cornell Medicine-Qatar, Education City, PO 24144, Doha, Qatar

${ }^{8}$ Lipidomics Consulting Ltd., Esbo, Finland

${ }^{9}$ Rosa \& Co LLC, San Carlos, CA, USA

10 University of Texas Health Science Center at San Antonio, San Antonio, TX, USA

${ }^{11}$ Department of Medicine, Duke University, Durham, NC, USA 
medRxiv preprint doi: https://doi.org/10.1101/2021.07.16.21260601; this version posted July 20, 2021. The copyright holder for this preprint (which was not certified by peer review) is the author/funder, who has granted medRxiv a license to display the preprint in perpetuity. It is made available under a CC-BY-NC-ND 4.0 International license .

${ }^{12}$ Duke Institute of Brain Sciences, Duke University, Durham, NC, USA

\begin{abstract}
Dysregulation of sphingomyelin (SM) and ceramide metabolism have been implicated in
\end{abstract} Alzheimer's Disease (AD). Genome-wide and transcriptome wide association studies have identified various genes and genetic variants in lipid metabolism that are associated with AD. However, the molecular mechanisms of sphingomyelin and ceramide disruption remain to be determined. Evaluation of peripheral lipidomic profiles is useful in providing perspective on metabolic dysregulation in preclinical and clinical AD states. In this study, we focused on the sphingolipid pathway and carried out multi-omic analyses to identify central and peripheral metabolic changes in AD patients and correlate them to imaging features and cognitive performance in amyloidogenic mouse models. Our multi-omic approach was based on (a) 2114 human post-mortem brain transcriptomics to identify differentially expressed genes; (b) in silico metabolic flux analysis on 1708 contextspecific metabolic networks to identify differential reaction fluxes; (c) multimodal neuroimaging analysis on 1576 participants to associate genetic variants in SM pathway with AD pathogenesis; (d) plasma metabolomic and lipidomic analysis to identify associations of lipid species with dysregulation in $A D$; (e) metabolite genome-wide association studies (mGWAS) to define receptors within pathway as potential drug target. Our findings from complementary approaches suggested that depletion of S1P compensated for AD cellular pathology, likely by upregulating the SM pathway, suggesting that modulation of S1P signaling may have protective effects in AD. We tested this hypothesis in APP/PS1 mice and showed that prolonged exposure to fingolimod, an S1P signaling modulator approved for treatment of multiple sclerosis, alleviated the cognitive impairment in mice. Our multi-omic approach identified potential targets in the SM pathway and suggested modulators of S1P metabolism as possible candidates for AD treatment. 
medRxiv preprint doi: https://doi.org/10.1101/2021.07.16.21260601; this version posted July 20, 2021. The copyright holder for this preprint

(which was not certified by peer review) is the author/funder, who has granted medRxiv a license to display the preprint in perpetuity.

It is made available under a CC-BY-NC-ND 4.0 International license .

\section{Introduction}

To date, approximately 400 trials of experimental Alzheimer's treatments have failed ${ }^{1}$. In the wake of such large-scale failure, additional hypotheses have been proposed to accelerate strategies for treatment and researchers are pursuing alternative approaches, with a greater focus on the complex mechanisms underlying this neurodegenerative disease. In an effort to address this knowledge gap, the NIH-funded Accelerating Medicines Partnership - Alzheimer's Disease (AMP-AD) has successfully generated new hypotheses and insights around Alzheimer's disease (AD) and produced large, publicly available datasets. The knowledge gained from this initiative will lead a major paradigm shift in research focus, resulting in novel targets and testable hypotheses that are currently being investigated in clinical phase 1 and 2 trials aimed at neuroprotection and anti-neuroinflammation ${ }^{2}$. These new hypotheses also suggest potential drug repositioning and development.

While the central neuropathological features of $A D$ are accumulation of misfolded $\beta$ amyloid $(A \beta)$ plaques and phosphorylated tau proteins, brain atrophy and neuronal loss are equally important. The relationship between $A \beta$ accumulation, tau phosphorylation and neuronal loss is unclear. What is clear is that AD etiology is multifactorial, with genetic contributions, protein mis-trafficking and turnover, altered glucose metabolism and lipid metabolism failures ${ }^{3}$. Recent studies have clarified the important relationship between the immune system and lipid metabolism and more than half of the genes implicated in $A D$ via genetic association screens are linked to lipid metabolism and inflammation ${ }^{4}$. Exploring how these genes factor into AD pathophysiology over the last few years is starting to increase our understanding of the role of lipid metabolism in AD. APOE4, the strongest genetic risk factor for late onset $A D$, is centrally involved in lipid metabolism, including the transport of cholesterol to neurons from astrocytes ${ }^{5}$. Additionally, several independent genetic association studies have reported replicable associations of the APOE locus with blood levels of sphingolipid species ${ }^{6,7,8}$. Lipids, including SMs, have been shown to be disrupted in $A D^{9,10,11}$. However, the impact of lipid dysregulation on $A D$ pathogenesis are not fully understood. 
medRxiv preprint doi: https://doi.org/10.1101/2021.07.16.21260601; this version posted July 20, 2021. The copyright holder for this preprint (which was not certified by peer review) is the author/funder, who has granted medRxiv a license to display the preprint in perpetuity. It is made available under a CC-BY-NC-ND 4.0 International license .

Brain lipids constitute $\sim 50 \%$ of the brain's dry weight with myelin, a proteolipid, composed of $70-80 \%$ lipids $^{12}$. Several lines of supporting evidence implicate various sphingolipids in neuronal signaling and toxicity ${ }^{13,14}$. Sphingomyelin (SM) primarily resides in two locations within the brain: 1) Lipid rafts, found in neurons, astrocytes, and microglia where they are involved in several aspects of signal transduction and homeostasis of the brain; 2) the membranous myelin sheath that insulates many nerve cell axons ${ }^{15}$. As part of lipid rafts, SMs are involved in signal transduction and the regulation of inflammatory processes and response to oxidative stress ${ }^{16}$. Our previous studies ${ }^{17-20}$ indicated a complex pattern of deregulation in the sphingolipid metabolism, including ceramides, in the early stages of $A D$. We have also reported changes at the gene expression level of the myelin network in $A D^{21}$. Hydrolysis of sphingomyelin produces ceramide (Cer). Ceramides are the simplest of sphingolipids, are neurotoxic and induce apoptosis ${ }^{22,23}$. Ceramides are known to mediate the relationship between $A \beta$ and neurodegeneration ${ }^{24}$. Increasing $A \beta$ levels elevate SM phosphodiesterase (SMase) activity leading to an increase in $\mathrm{Cer}^{25,26}$. It is suggested that the increase in ceramides boosts BACE-1 activity ${ }^{27}$, which cleaves APP in two soluble $A \beta$. Sphingosine-1-phosphate (S1P), is an important neuroprotective signaling molecule and product of the SM pathway that blocks SMase activity ${ }^{28}$ and inhibits amyloid precursor protein (APP) secretion ${ }^{29}$. By understanding the changes in SM/Cer homeostasis and their underlying mechanism, we can better understand how perturbations in the SM pathway contribute to neurodegeneration.

As part of normal homeostasis, microglia constantly surveil the brain parenchyma. In development, and throughout normal life-span, they remove neuronal synapses, eliminate dying neurons, and clean up myelin debris ${ }^{30-33}$. Sphingolipid-rich neuronal and myelin membranes captured through these processes undergo lysosomal degradation within microglia. This degradative process is facilitated by a lipid-sensing receptor, TREM2, that is activated by various lipids (including sphingolipids, sphingomyelin, and sulfatide). TREM2-deficient microglia phagocytose myelin debris but fail to clear myelin cholesterol, resulting in cholesteryl ester (CE) accumulation. CE increase is also observed in APOE-deficient glial cells, reflecting impaired brain cholesterol transport ${ }^{34}$. 
medRxiv preprint doi: https://doi.org/10.1101/2021.07.16.21260601; this version posted July 20, 2021. The copyright holder for this preprint (which was not certified by peer review) is the author/funder, who has granted medRxiv a license to display the preprint in perpetuity. It is made available under a CC-BY-NC-ND 4.0 International license .

Recent studies have begun to elucidate the important role of microglia in $A D$, with evidence for differences in microglial subpopulations, related to myelin clearance and activation $^{35-41}$.

In this study, we used human in vivo data and post-mortem brain data to finely characterize the SM pathway for molecular links to AD pathogenesis. We identified metabolic readouts that can be utilized to link observed molecular changes back to potential intervention targets, which were experimentally validated in animal models resulting in repurposed drug for $A D$. We started with gene expression profiling from three large cohorts to identify differentially expressed genes in the SM pathway. We then utilized constraint-based modeling to narrow down the search space to identify potential changes in metabolic fluxes between cognitively normal and $A D$ individuals. Next, we identified genetic variants within SM pathway and their association with changes in neuroimaging using large multicenter biomarker study. We then identified changes in plasma lipidomic species within the SM pathway with specific SNPs using data from ADNI and AIBL cohort. Using complementary approaches, we identified sphingosine 1phosphate (S1P) regulating the balance in the pathway. We tested our hypothesis and demonstrated that fingolimod, a S1P receptor (S1PR) modulator which causes internalization of S1PR, is able to improve cognition in APP/PS1 mice. We highlight S1P as the metabolite involved in maintaining the balance in the pathway and identifying drugs regulating S1P levels that can be repurposed for $A D$.

\section{Results}

\section{Global transcriptomic dysregulation of the SM pathway in AD}

We analyzed gene expression changes of well-characterized enzymes in the sphingolipid pathway from post-mortem brain RNA-seq data generated on seven brain regions (cerebellum, temporal cortex, dorsolateral prefrontal cortex, parahippocampal gyrus, frontal pole, inferior frontal gyrus and superior temporal gyrus) in three independent 
medRxiv preprint doi: https://doi.org/10.1101/2021.07.16.21260601; this version posted July 20, 2021. The copyright holder for this preprint (which was not certified by peer review) is the author/funder, who has granted medRxiv a license to display the preprint in perpetuity. It is made available under a CC-BY-NC-ND 4.0 International license .

cohorts (ROS/MAP, Mayo and Mount Sinai), of 2114 brain samples as well as the crossregion, cross-study meta-analysis ${ }^{42}$. For this study, we manually curated the sphingolipid subsystem definition of the human genome-scale metabolic reconstruction ${ }^{43}$ resulting in the identification of a set of 35 enzymes catalyzing 18 enzymatic reactions within the SM pathway (Figure 1, Supplementary Table 1). The reactions cover Cer and SM biosynthesis, as well as four exit routes (through sphinganine-1-phosphate, ceramide-1phosphate, sphingomyelin, glycosphingolipids and sphingosine-1-phosphate). Gene expression data was available for 31 of the 35 genes, the exceptions being CERS3, ACER1, ASAH2 and ENPP7. Low and/or no expression of these genes in the brain was confirmed in the GTEx Portal.

Analysis of differential gene expression showed significant (FDR-corrected) gene expression changes in brain tissue of $A D$ cases vs. controls for 20 of the genes (Supplementary Table 2). Of those 20, 19 showed differential expression in one or more studies/brain regions. Fourteen of these were also detected in the meta-analysis. Transcripts of SPTLC3 were not measured in all brain regions, hence it was not reported in the meta-analysis. DEGS1, on the other hand, was insignificantly but consistently upregulated in the single studies, leading to a detectable significant overall upregulation in the meta-analysis. Almost all of the genes showed significantly higher expression in $A D$ cases, consistent across all brain regions. Exceptions were CERS5 (lower levels in cerebellum of AD cases; not significant in the meta-analysis), CERS6 (higher levels in cerebellum vs. lower levels in the parahippocampal gyrus of AD cases; not significant in the meta-analysis), and SMPD3 (lower levels in temporal cortex of AD cases; also significant in the meta-analysis). 
medRxiv preprint doi: https://doi.org/10.1101/2021.07.16.21260601; this version posted July 20, 2021. The copyright holder for this preprint (which was not certified by peer review) is the author/funder, who has granted medRxiv a license to display the preprint in perpetuity.

It is made available under a CC-BY-NC-ND 4.0 International license .

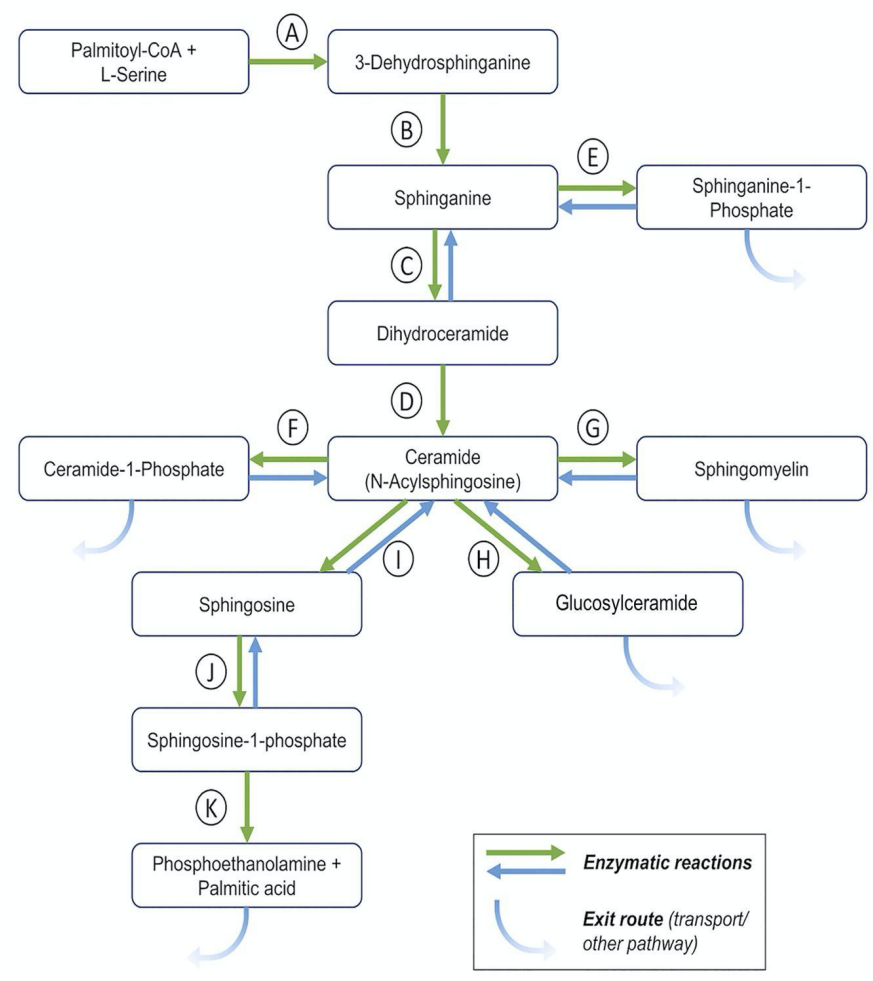

\begin{tabular}{|c|c|c|}
\hline $\begin{array}{l}\text { Serine C-Palmitoyltransferase } \\
(S P T)\end{array}$ & A & \\
\hline $\begin{array}{l}\text { 3-Dehydrosphingosine } \\
\text { reductase }\end{array}$ & B & \\
\hline $\begin{array}{l}\text { Sphingasine } \mathrm{N} \text { - } \\
\text { Acyltransferase/ Ceramide } \\
\text { synthase (CERS) }\end{array}$ & C & Ceramidase (ACER) \\
\hline Dihydroceramide desaturase & D & \\
\hline $\begin{array}{l}\text { Sphingolipid long chain base } \\
\text { kinase }\end{array}$ & $E$ & $\begin{array}{l}\text { 3-Sn-Phosphatidate } \\
\text { phosphohydrolase }\end{array}$ \\
\hline Ceramide kinase (CERK) & $F$ & Phosphatidate phosphatase \\
\hline $\begin{array}{l}\text { Sphingomyelin synthase } \\
\text { (SGMS) }\end{array}$ & G & $\begin{array}{l}\text { Sphingomyelin } \\
\text { phosphodiesterase (SMPD) }\end{array}$ \\
\hline Ceramide glucosyltransferase & H & Glucosylceramidase \\
\hline Ceramidase & 1 & $\begin{array}{l}\text { Sphingosine } \mathrm{N} \text { - } \\
\text { acyltransferase / Ceramide } \\
\text { synthase }\end{array}$ \\
\hline Sphingosine kinase & $\mathbf{J}$ & $\begin{array}{l}\text { Sphingosine-1-phosphate } \\
\text { phosphatase / Phosphatidate } \\
\text { phosphatase (SGPP) }\end{array}$ \\
\hline $\begin{array}{l}\text { Sphingosine-1-phosphate } \\
\text { lyase (SGPPL) }\end{array}$ & $\mathbf{K}$ & \\
\hline
\end{tabular}

Figure 1: Overview of sphingolipid pathway manually curated from the Recon3D model. The metabolites participating in reactions are represented in boxes. The arrows for reactions A-K are colored based on the direction in the pathway. Some reactions are not reversible (single arrows). The table on the right lists the catalyzing enzymes in the sphingolipid pathway in humans and are denoted with the same color code as the reaction arrow.

Differential reaction fluxes for SM and Cer associated reactions

We used brain region-specific metabolic reconstructions ${ }^{44}$ and integrated the postmortem brain RNA-seq data with them to identify reactions that had differential fluxes in $A D$ vs cognitively normal $(C N)$ or control individuals. For the dorsolateral prefrontal cortex, we identified reactions catalyzed by serine palmitoyltransferase (SPT, encoded by SPTLC1/2/3, enzyme $A$ in Figure 1), sphingomyelin synthase (SMS, encoded by SGMS1/2, enzyme $G$ in Figure 1), and ceramide kinase (CERK, encoded by CERK, enzyme $F$ in Figure 1) as having significant flux differences as shown in Figure 2. SPT 
medRxiv preprint doi: https://doi.org/10.1101/2021.07.16.21260601; this version posted July 20, 2021. The copyright holder for this preprint (which was not certified by peer review) is the author/funder, who has granted medRxiv a license to display the preprint in perpetuity. It is made available under a CC-BY-NC-ND 4.0 International license.

catalyzes the first step in the biosynthesis of sphingolipids condensing serine and palmitoyl-CoA to form 3-ketosphinganine, which is the rate-limiting step in the synthesis of SMs (Figure 1). For this reaction, we found significant differences in flux values comparing $\mathrm{AD}$ and mild cognitive impairment (MCI) cases (Figure 2A). Sphingomyelin synthase synthesizes sphingomyelin from ceramide. Here, we observed AD transcriptomes having higher reaction fluxes compared to the CN samples (Figure 2B). We further identified flux differences for the reaction catalyzed by ceramide kinase (phosphorylation of ceramide to form ceramide-1-phosphate) in $A D$ and $C N$ samples (Figure 2C).

A)

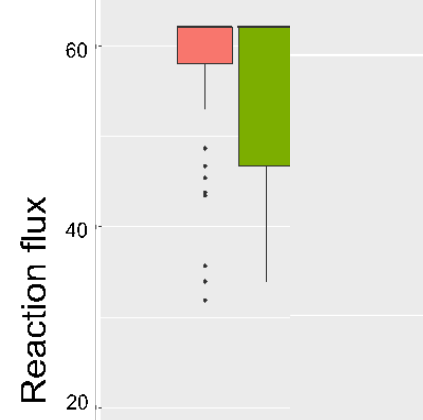

B)

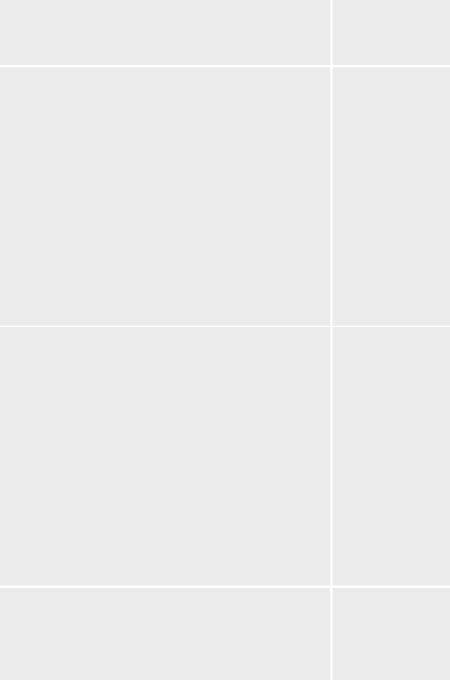

C)

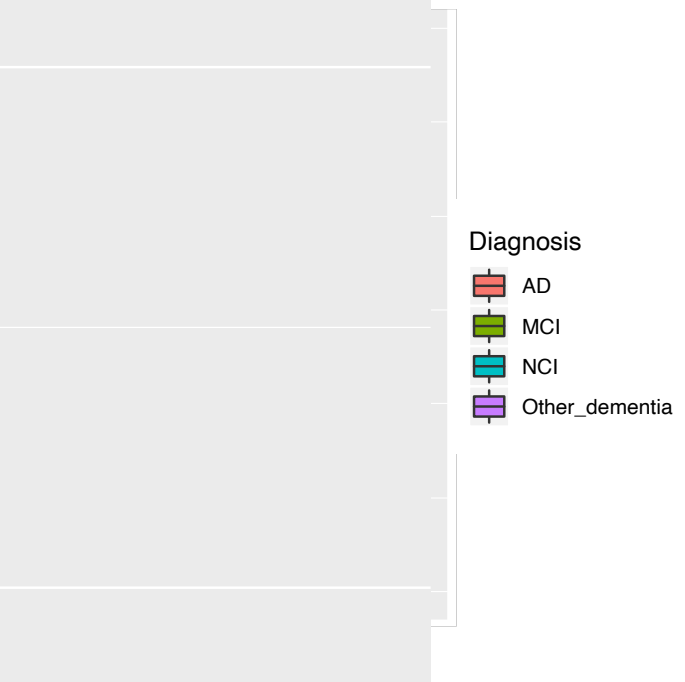

Figure 2: Box plot of reaction fluxes for (a) serine palmitoyl transferase, (b) sphingomyelin synthase, and (c) ceramide kinase reactions. The orange, green, blue and purple bars correspond to $\mathrm{AD}, \mathrm{MCl}, \mathrm{NCl}$ and other dementia.

Genetic association studies and multimodal neuroimaging analysis link SM pathway to $\underline{A D}$ pathogenesis

Using gene-based association analysis in 1,576 participants of the AD Neuroimaging Initiative (ADNI) phases 1, GO and 2, we identified genetic variants in the coding regions linked to seven of the 35 genes in the SM pathway to be significantly associated with AD and its (bio)markers, which covered the whole spectrum of Amyloid, Tau, Neurodegeneration, Cognition (A-T-N-C) measures ${ }^{45}$ (Supplementary Table 3). A-T-N-C 
medRxiv preprint doi: https://doi.org/10.1101/2021.07.16.21260601; this version posted July 20, 2021. The copyright holder for this preprint (which was not certified by peer review) is the author/funder, who has granted medRxiv a license to display the preprint in perpetuity. It is made available under a CC-BY-NC-ND 4.0 International license .

measures of $A D$ are calculated by investigating genetic associations of CSF biomarker levels, brain atrophy (magnetic resonance imaging), brain glucose metabolism ([18F]FDG PET), cognition, and clinical diagnosis. In this analysis, Bonferroni-significance was determined by gene-specific thresholds correcting for the number of all genetic variants assigned to a certain gene. Associated markers included CSF $A \beta_{1-42}$ (CERS2, enzyme $C$ in Figure 1), the ratio between CSF tau (both total tau and p-tau) and CSF $A \beta_{1-42}(A C E R 2$ (enzyme $C$ in Figure 1), PLPP2), region of interest-based measures of $\left[{ }^{18} \mathrm{~F}\right]$ fluorodeoxyglucose positron emission tomography (FDG-PET; CERS3, SPHK2), cognitive performance measured, among other, by the 13-item cognitive subscale of the $\mathrm{AD}$ assessment scale (ADAS-Cog.13; CERS6, DEGS1), and clinical AD (CERS3, CERS6, DEGS1). Furthermore, a detailed whole brain analysis of brain glucose metabolism (FDG PET) on a voxel-wise levels showed that rs1847325 in CERS3 (enzyme $\mathrm{C}$ in Figure 1) and rs281380 in SPHK2 ( $\mathrm{J}$ in Figure 1) were significantly associated with increased brain glucose metabolism in the bilateral frontal, parietal, and temporal lobes (colored regions with corrected p-value < 0.05; Supplementary Figure 1). Previously, a study on clinico-pathologic AD dementia ${ }^{46}$ yielded an association with SMPD2 (enzyme G in Figure 1) that is Bonferroni-significant at the gene-wide level.

A less stringent $p$-value cutoff (adjusting for multiple testing by permutation as SNPs are correlated due to linkage disequilibrium) identified variants in two additional genes, SPTLC3 (enzyme A in Figure 1) and SGMS1 (enzyme G in Figure 1). SPTLC3 was associated with cognitive performance (corrected $p$-value $=0.02$; Figure $3 \mathrm{~A}$ ), brain atrophy in focal regions of the bilateral temporal and frontal lobes (determined by detailed surface-based whole-brain analysis of cortical thickness measured from MRI scans on a vertex-wise level; colored regions with corrected p-value < 0.05; Figure 3B) and FDGPET measures in the bilateral temporal and parietal lobes (colored regions with corrected p-value < 0.05; Figure 3C). SGMS1 was associated with brain glucose metabolism measured by region of interest-based FDG-PET (corrected p-value $=0.02$; Figure 3D) that was mapped by whole brain analysis to the bilateral temporal, parietal, and frontal lobes, as well as the hippocampus (colored regions with corrected p-value < 0.05; Figure 
medRxiv preprint doi: https://doi.org/10.1101/2021.07.16.21260601; this version posted July 20, 2021. The copyright holder for this preprint (which was not certified by peer review) is the author/funder, who has granted medRxiv a license to display the preprint in perpetuity.

It is made available under a CC-BY-NC-ND 4.0 International license .

3F). In addition, surface-based whole brain association analysis showed a significant association with cortical thickness in the bilateral temporal, parietal, and frontal lobes, with the strongest association located in the entorhinal cortex (colored regions with corrected p-value < 0.05; Figure 3E).

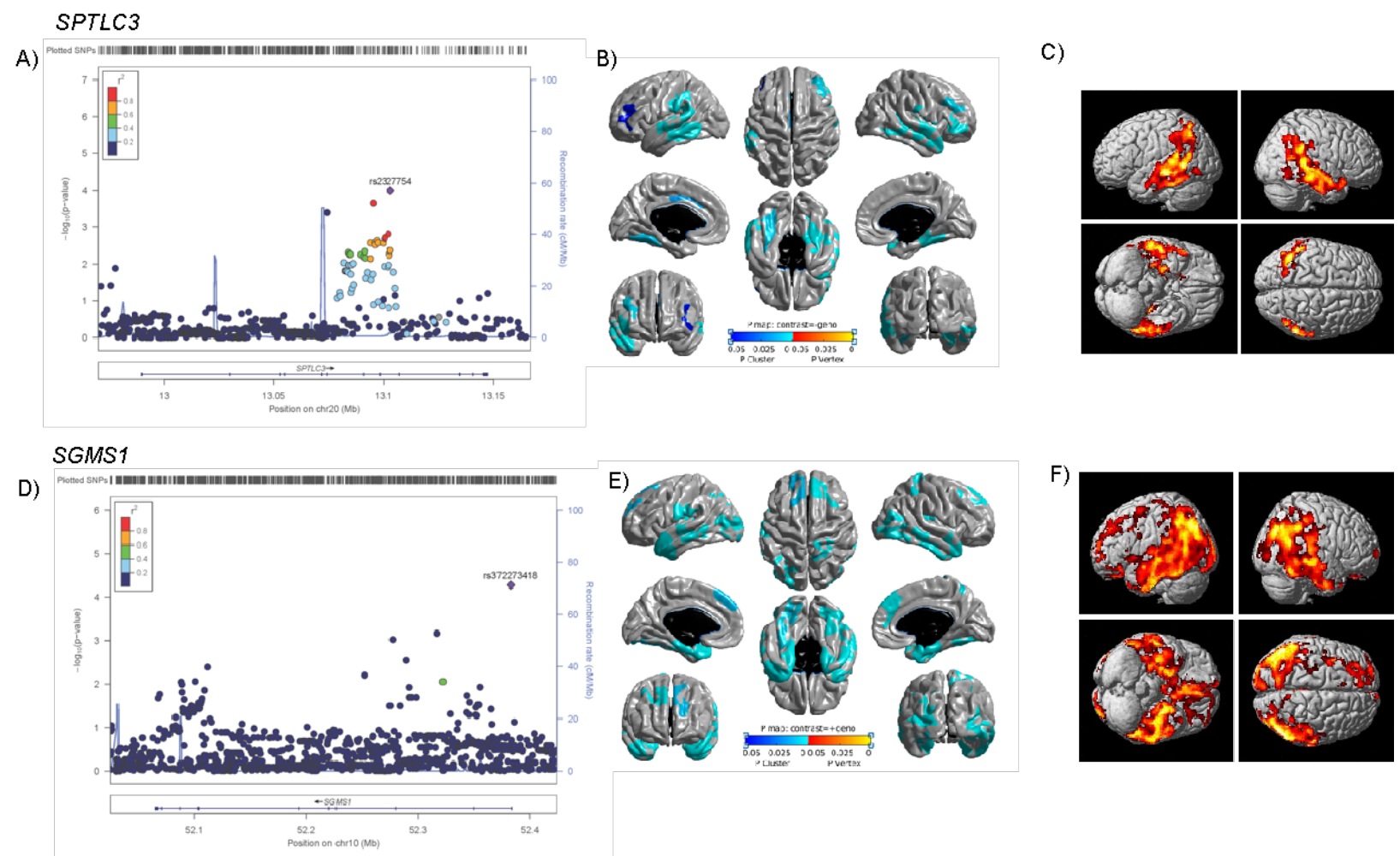

Figure 3: Association of genetic variants in SPTLC3 and SGMS1 with structural (MRI) and molecular (FDG-PET) neuroimaging phenotypes. A) Gene-based association analysis of SPTLC3 with cognitive performance (Rey auditory verbal learning test total score). D) Gene-based association analysis of SGMS1 with global brain glucose metabolism. B \& E) Surface-based whole brain analysis of cortical thickness (brain atrophy measured from MRI scans) for SPTLC3 and SGMS1. C \& F) Voxel-based whole brain analysis of brain glucose metabolism measured from FDG PET scans for SPTLC3 and SGMS1.

SM (d34:1)/SM (d43:1) ratio as a strong intermediate trait for sphingolipid dysregulation $\underline{\text { in } A D}$

Sphingomyelin species (SMs) of differing lengths have been implicated in early vs. late stages of $A D^{19}$. SM (d34:1) is associated with CSF $A \beta 1-42$ pathology, while SMs with 
medRxiv preprint doi: https://doi.org/10.1101/2021.07.16.21260601; this version posted July 20, 2021. The copyright holder for this preprint (which was not certified by peer review) is the author/funder, who has granted medRxiv a license to display the preprint in perpetuity. It is made available under a CC-BY-NC-ND 4.0 International license .

longer fatty acid chains ( $\geq \mathrm{C} 20)$ are correlated with brain atrophy and cognitive decline. Utilizing the concept of metabolite ratios $^{47}$, which enables both removal of potentially remaining technical variance and modeling of enzymatic/pathway activity ${ }^{8}$, we selectively screened ratios of shorter chain SMs $(<C 20)$ and longer chain SMs $(\geq C 20)$ in the ADNI1 dataset $(n=732)$ similar to Toledo et al. ${ }^{19}$. This revealed the ratio of SM $(d 34: 1)$ and SM (d43:1) as the metabolic trait most significantly associated with diagnosis of clinical $A D\left(p-v a l u e=1.70 \times 10-4, P_{\text {gain }}=178.37\right)$, brain atrophy in regions implicated in $A^{48}(p-$ value $=7.64 \times 10-6, P_{\text {gain }}=687.57$ ) as well as cognition (measured by ADAS-Cog. 13; $p$ value $\left.=4.36 \times 10-6, \mathrm{P}_{\text {gain }}=2544.51\right)$. The modified Alzheimer's Disease Assessment Scale cognitive subscale (ADAS-Cog 13-item scale) ${ }^{49}$ has all the original ADAS-Cog items with additional items that were aimed to increase the number of cognitive domains and range of symptom severity.

To expand upon and further validate this finding, we examined the same cohort (ADNI1) using a more comprehensive lipidomics method covering a broader range of sphingolipids. In total, 112 sphingolipids were examined in serum samples $(\mathrm{n}=754)$, where chromatography enabled separation of some isomeric and isobaric species. Regression analysis (adjusting for age, sex, BMI, HDL-C, total cholesterol, triglycerides, APOE e4 and fasting status) between individual lipid species and lipid ratios (112 individual species, totaling 12,544 ratios) with ADAS-Cog 13 identified 3385 ratios associated with an uncorrected $p$-value of $<0.05$ and 1552 significant post FDR correction (Supplementary Table 4). This analysis confirmed that ratios of short to longer chain sphingomyelins, in particular the ratio of $\operatorname{SM}(d 34: 1) / S M(d 43: 1)$, presented with a positive association with ADAS-Cog 13 scores (FDR corrected p-value of $3.98 \times 10^{-2}$ ).

\section{Using the SM species for genetic screening and pathological markers in $A D$}

To link SM readouts associated with AD to genes, we performed metabolite genome-wide association studies (mGWAS) with the three SMs reported to be associated with markers 
medRxiv preprint doi: https://doi.org/10.1101/2021.07.16.21260601; this version posted July 20, 2021. The copyright holder for this preprint (which was not certified by peer review) is the author/funder, who has granted medRxiv a license to display the preprint in perpetuity. It is made available under a CC-BY-NC-ND 4.0 International license .

of $A D$ in Toledo et al., as well as the selected ratio of SM(d34:1)/SM(d43:1). The discovery analysis was performed in a subset of $674 \mathrm{ADNI}-1$ participants from Toledo et al. ${ }^{19}$ that had genome-wide genotyping data available. While the three single SM species did not yield significant results, the SM ratio was associated with SPTLC3 (enzyme A in Figure 1) at genome-wide significance corrected for 4 metabolic traits (lead SNP rs680379, pvalue $\left.=1.01 \times 10^{-9}\right)$. This association replicated a previous finding in a larger populationbased mGWAS investigating metabolite ratios ( $r$ 168622, $r^{2}=0.98$ with rs680379, $p$ value $\left.=5.2 \times 10^{-25}\right)^{20}$.

Lookup of the SPTLC3 (enzyme $A$ in Figure 1) locus using the large collection of metabolite-genotype associations in the SNiPA database ${ }^{50}$ ) revealed significant links to several additional SM species. To obtain a comprehensive map of genetic influences on SM levels across the whole SM pathway, we again used gene-based association analyses including all 35 genes in the pathway analogously to the analysis of associations with markers of $A D$. To this end, we used an expanded set of 1,407 ADNI participants with SM readouts and genome-wide genotype information available, as well as two large population-based mGWAS studies that included SM levels ${ }^{6,8}$. We found genome-wide and gene-wide significant associations with a set of 14 related SMs for six genes (Figure 4, Supplementary Table 5). Three of the encoded enzymes are involved in SM synthesis (SPTLC3, CERS2, CERS4), while the other three function in synthesis and degradation of S1P (SPHK2, SGPP1, SGPL1), a central exit route of the pathway. Notably, the significant associations include all three SMs identified by Toledo et al. ${ }^{19}$ (SM (d33:0), SM (d34:1), and SM (d38:2)), highlighting a potential role for S1P metabolism and signaling in $A D$ pathogenesis. 
medRxiv preprint doi: https://doi.org/10.1101/2021.07.16.21260601; this version posted July 20, 2021. The copyright holder for this preprint (which was not certified by peer review) is the author/funder, who has granted medRxiv a license to display the preprint in perpetuity. It is made available under a CC-BY-NC-ND 4.0 International license .



Figure 4: Hybrid network of genetic associations revealed by gene-based association studies and significant partial correlations of detected sphingomyelins ${ }^{8,19}$. The six identified genes can be grouped into two categories: global sphingomyelin synthesis and synthesis and degradation of sphingosine-1-phosphate. The selected SM ratio is colored in orange, other SM species are in green (light green: non-targeted metabolomics in Shin et al. ${ }^{8}$; dark green: targeted metabolomics in ADNI and Draisma et al. ${ }^{6}$ ), and genes are in dark yellow.

\section{Treatment of amyloidogenic APP/PS1 mice with Fingolimod}

To functionally investigate involvement of deregulated S1P metabolism in amyloid pathology along with strategies to counter potentially links to $A D$ pathogenesis, we applied a drug repositioning approach by treating amyloidogenic APP/PS1 mice with fingolimod (FTY720), an FDA-approved drug for the use in the relapsing-remitting form of multiple sclerosis ${ }^{51}$. The APP/PS1 mice are transgenic mice expressing chimeric amyloid precursor protein (APP) and mutant human presenilin 1 (PS1) and are valuable models to study $A D$ progression and effect of drugs on $A D^{52}$. The immunomodulating compound is a sphingosine analog that, after endogenous phosphorylation by sphingosine kinases 1 and 2, broadly binds to S1P receptors (S1PR1/3/4/5) $)^{53,54}$. 
To corroborate previously published data with similar ages, we phenotyped APP/PS1 ( $\mathrm{n}$ $=6,50 \%$ female $)$ and WT mice ( $n=6,50 \%$ female) at 7 months old (m.o.) using a battery of behavioral tests. Novel object recognition (NOR) test and Barnes Maze task were utilized to assess episodic and spatial memory respectively. After behavioral testing, we evaluated synaptic transmission using electrophysiology experiments at the Schaffer collateral-CA1 synapse. APP/PS1 mice had a significant deficit in the NOR test (Discrimination index $(\mathrm{DI})=-0.18 \pm 0.18$, Figure $5 \mathrm{~A}$ ) compared to WT mice (DI $=0.33 \pm$ $0.24 ; t_{5}=3.25 ; p$-value $\left.=0.02\right)$. During the Barnes Maze task APP/PS1 mice showed a mild deficit in spatial learning abilities $\left(t_{36}=3.098 ; p\right.$-value $=7.5 \times 10^{-3}$ on $1^{\text {st }}$ day and $t_{36}$ $=3.156 ; p$-value $=7.5 \times 10^{-3}$ on $2^{\text {nd }}$ day (Figure $5 \mathrm{~B}$ ) and memory retention showed by the less time spent in the target quadrant $\left(30.39 \pm 4.8\right.$ vs. $57.97 \pm 4.4, t_{8}=3.939 ; p$-value $=4.3 \times 10^{-3}$ ) (Figure 5C) compared to their WT littermates. Furthermore, they showed abnormal long term potentiation (LTP) both at the early and maintenance phase in the CA3-CA1 synapse (Figure 5D,E,F), where APP/PS1 mice could not maintain the potentiation 40 min after HFS $(112.7 \% \pm 1.8)$ compared to WT mice $\left(188.4 \% \pm 3.06 ; F_{(1,38)}\right.$ $=95.37, p$-value $<0.0001)$. Of note, basal synaptic transmission as evaluated by the input-output relationship was similar in the two groups (data not shown). 
A

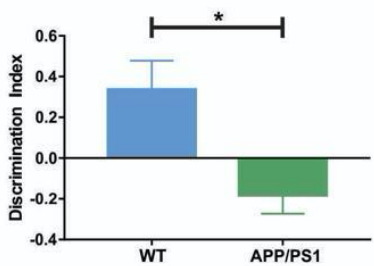

D

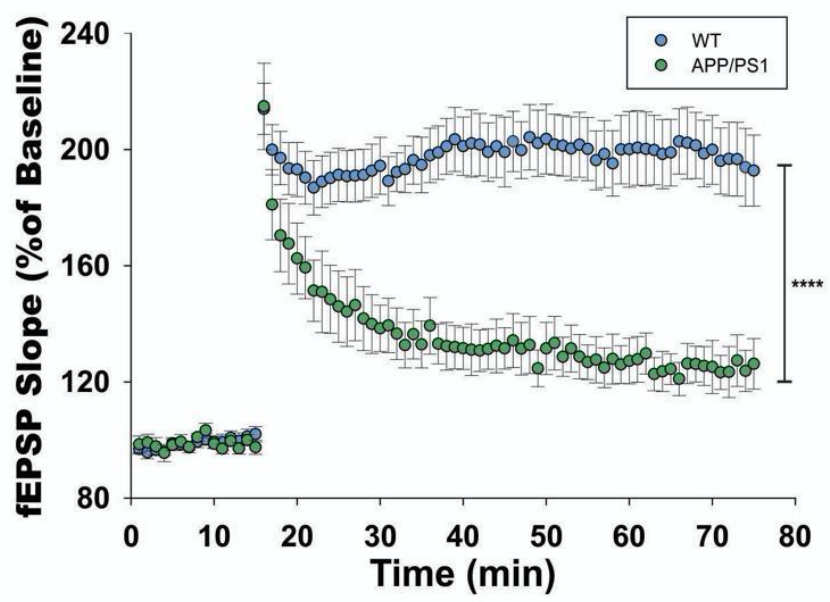

G

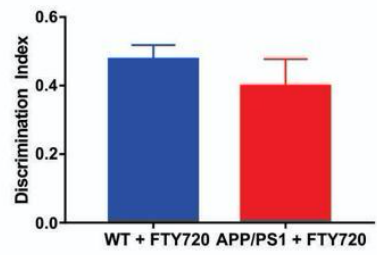

$\mathbf{J}$

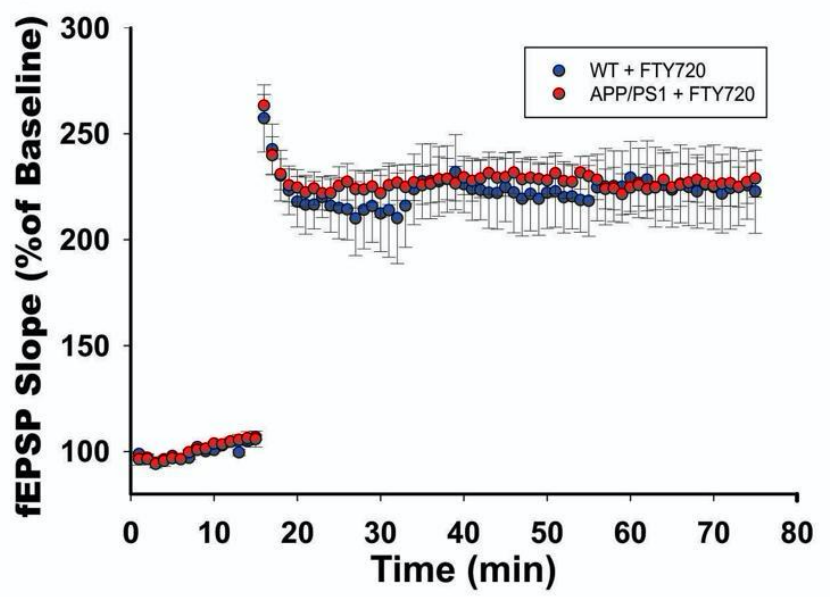

C

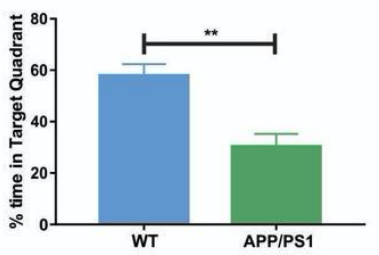

E
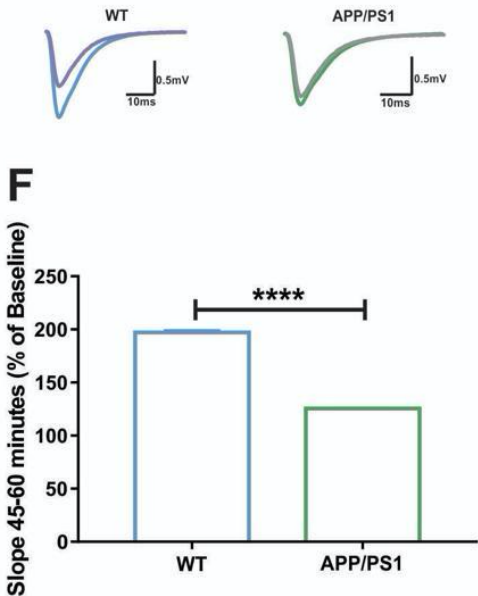

I

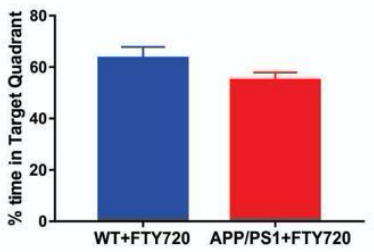

K

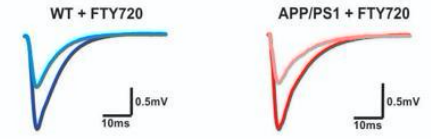

L

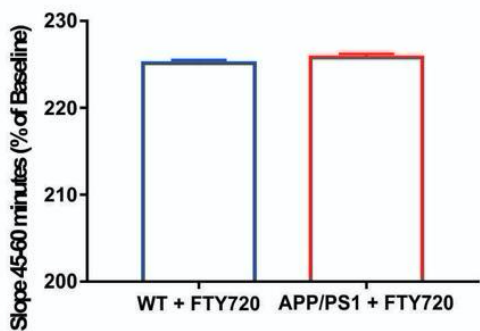


medRxiv preprint doi: https://doi.org/10.1101/2021.07.16.21260601; this version posted July 20, 2021. The copyright holder for this preprint (which was not certified by peer review) is the author/funder, who has granted medRxiv a license to display the preprint in perpetuity. It is made available under a CC-BY-NC-ND 4.0 International license .

Figure 5. APP/PS1 mice hippocampal dependent behavior and synaptic transmission assessment and effect of fingolimod treatment.

A. Exploration time spent on the novel object in the NOR test session. Data is expressed as a discrimination index \pm SEM. B. Barnes maze performance during training days. Acquisition learning trials were performed, and the time it took to locate and enter into the escape box was reported in seconds. The average performance of four trials per day was expressed as mean \pm SEM. A shorter latency indicates faster spatial learning. C. Probe trial was performed on day 5 of the Barnes Maze protocol, during which the escape box was removed. The percentage of time spent inside the target quadrant (the previous escape box location) is plotted \pm SEM. A larger percentage of time indicates better spatial memory. D. LTP timeline. Plotted are normalized evoked excitatory post-synaptic potentials (EPSPs) slopes (Y) vs. recording time (X). The first 20 min of evoked responses were normalized and used as the baseline responses of LTP. E. Representative analog traces of evoked EPSPs before (light purple and grey) and after (blue and green) high frequency stimulation (HFS). F. The magnitude of LTP was determined according to the responses between 45 and 60 min after the HFS. Data represent mean fEPSP Slope \pm SEM. ( $n=6$ mice in each group). G. APP/PS1 mice treated with fingolimod were tested in NOR task. Data is expressed as a discrimination index \pm SEM. Fingolimod treatment significantly enhance the discrimination index of the APP/PS1 mice. H. Average performance of four trials per day expressed as mean \pm SEM and I. Percentage of time spent inside the target quadrant \pm SEM at the Barnes Maze task of APP/PS1 fingolimod treated mice. Fingolimod mitigated the spatial learning deficits of the APP/PS1 at 9 mo. J. LTP of the CA3 to CA1 synapse timeline. K. Representative analog traces of evoked EPSPs before (light blue and light red) and after (blue and red) HFS. L. The APP/PS1 treated mice group significantly augmented the normalized slope of fEPSP after HFS. 
medRxiv preprint doi: https://doi.org/10.1101/2021.07.16.21260601; this version posted July 20, 2021. The copyright holder for this preprint (which was not certified by peer review) is the author/funder, who has granted medRxiv a license to display the preprint in perpetuity. It is made available under a CC-BY-NC-ND 4.0 International license .

In the second experiment, mice were treated with fingolimod ( $1 \mathrm{mg} / \mathrm{Kg} /$ day) for eight weeks (APP/PS1, $n=6,50 \%$ female; WT, $n=6,50 \%$ female; all mice 7 m.o. at the beginning of treatment). We found that fingolimod-treated APP/PS1 mice had similar values in NOR-DI as compared to treated WT mice $\left(0.40 \pm 0.13\right.$ vs. $0.47 \pm 0.08$; $t_{6}=0.95$; p-value $=0.38)($ Figure $5 G)$. Comparison of APP/PS1 treated vs. WT treated mice shows that the percentage of time spent in the target quadrant for treated APP/PS1 was similar to treated WT mice $\left(54.81 \pm 9.15\right.$ vs. $63.46 \pm 11.51, \mathrm{t}_{14}=1.677 ; \mathrm{p}$-value $\left.=0.12\right)$ (Figure 5I). Latency across training days also showed no difference between groups $\left(t_{3}=0.4697\right.$; p-value $=0.67)($ Figure $5 \mathrm{H})$. Remarkably, fingolimod treatment of APP/PS1 mice significantly augmented the normalized slope of fEPSP at the CA3 to CA1 synapse after HFS (Figure 5J,K). Comparison of the average slope percent change during the last 20 min of the maintenance phase also showed no difference $(225.8 \% \pm 1.86$ vs. $225.1 \% \pm$ $\left.1.78 ; t_{38}=1.163 ; p=0.25\right)$ (Figure $\left.5 \mathrm{~L}\right)$.

We then compared APP/PS1 fingolimod treated vs. untreated APP/PS1 (9 m.0. 50\% female, $n=6$ treated, $n=4$ untreated), and analysis of the latency during training showed a deficit in untreated compared to treated APP/PS1 mice (RM-ANOVA F $=3.1 ; p=0.041)$ (Supplementary Figure 2). These data indicate that prolonged S1P pathway modulation can rescue both the proposed cellular mechanism of hippocampus related memory (synaptic LTP) and the cognitive deficits per se in amyloidogenic APP/PS1 mice.

\section{Discussion}

In this study, we systematically analyzed the SM pathway for multi-omics links to pathogenic processes in AD. An overview of this study is shown in Figure 6. We were able to replicate the findings in human post-mortem samples, in vivo samples and mouse models. The key findings from the multi-omics work are: a) Using post-mortem brain transcriptome data of 2114 samples, we identified differentially expressed genes in the SM pathway of AD patients; b) comparison of 1708 context-specific metabolic reconstruction of the brain regions showed differences in the reaction fluxes for AD and 
medRxiv preprint doi: https://doi.org/10.1101/2021.07.16.21260601; this version posted July 20, 2021. The copyright holder for this preprint (which was not certified by peer review) is the author/funder, who has granted medRxiv a license to display the preprint in perpetuity.

It is made available under a CC-BY-NC-ND 4.0 International license .

CN samples; c) multimodal neuroimaging analysis of 1576 individuals identified genetic variants linked to genes in SM pathway and associated with AD pathogenesis; d) plasma metabolomic and lipidomic analysis identified the $\mathrm{SM}(\mathrm{d} 43: 1) / \mathrm{SM}(\mathrm{d} 34: 1)$ ratio as a strong intermediate trait for sphingolipid dysregulation in $A D$; e) metabolite genome-wide association studies (mGWAS) identified S1P metabolite as potential AD drug target; and f) experimental analyses of amyloidogenic APP/PS1 mice treated with fingolimod revealed beneficial effects of S1P modulation and alleviated the cognitive impairment in mice.

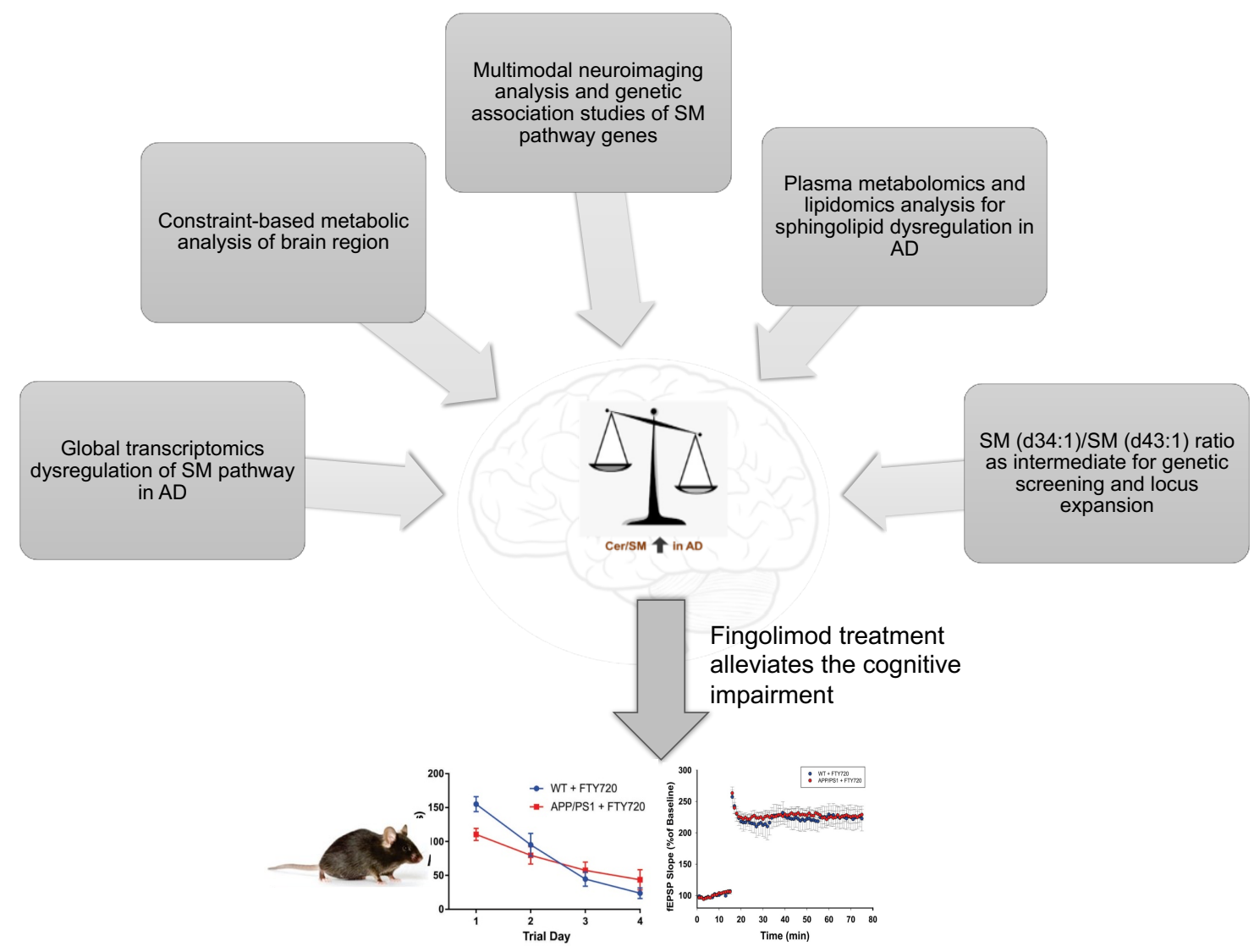

Figure 6: Overview of the study. We used information obtained from (a) post-mortem brain transcriptomics analysis; (b) metabolic networks of brain regions; (c) genetic variants associated with AD biomarkers including neuroimaging endophenotypes (MRI and FDG PET); (d) plasma metabolomics and lipidomics analysis; (e) genetic screening using SM (d43:1)/SM (d34:1) ratio. The balance of ceramide and sphingomyelin levels in $A D$ could be maintained by modulating S1PR activity. The hypothesis was tested on APP/PS1 mice treated with fingolimod. 
medRxiv preprint doi: https://doi.org/10.1101/2021.07.16.21260601; this version posted July 20, 2021. The copyright holder for this preprint (which was not certified by peer review) is the author/funder, who has granted medRxiv a license to display the preprint in perpetuity. It is made available under a CC-BY-NC-ND 4.0 International license .

We demonstrated that, on the gene expression level, the SM pathway is globally dysregulated across brain regions in samples of $A D$ cases compared to controls. We found that 20 out of 35 genes encoding the core enzymes in the pathway are significantly differentially expressed in the $A D$ population. The only sub-pathway that appears to be unaffected by or uninvolved in the disease is the synthesis and recycling of glycosphingolipids. Using constraint-based metabolic networks of brain regions integrated with post-mortem brain transcriptome data, we further show that the differential expression of the enzymes involved in at least three reactions are predicted to result in significant flux differences in AD cases versus controls. While flux differences cannot be directly interpreted with respect to the resulting metabolic changes, there is ample evidence from metabolomics studies that the pathway exhibits differential output in AD.

We next assessed the association of genes in the SM pathway with A-T-N-C measures of $A D$ by investigating genetic associations of CSF biomarker levels, brain atrophy (magnetic resonance imaging), brain glucose metabolism ([ $\left.{ }^{18} \mathrm{~F}\right]$ FDG PET), cognition, and clinical diagnosis. Ten of the 35 genes in the pathway showed significant associations with at least one (endo)phenotype at the gene level. Although not genome-wide significant, this large coverage of genes in the SM pathway suggests that there might be at least a small fraction of genetic risk predisposition to $A D$ attributable to the pathway as a whole. Using SM levels as intermediate traits for genetic association, screening further revealed six central enzymes in the pathway to be genetically influencing levels of a network of 14 SM species. As all of the genetic variants associated with SM levels were linked to the respective enzymes via expression quantitative trait loci, this indicates that some of the genetic links between the pathway and markers of AD may be mediated by altered regulation of SM levels via genetically influenced differential gene regulation.

While associations from the analysis of differential gene expression in brain tissue as well as from the phenotype GWASs were broad and generally implicated SM pathway function, the associations from the SM mGWASs linked two central pathway routes: global SM synthesis and S1P metabolism. Based on previous mGWAS analysis, genetic associations with core enzymes involved in the primary synthesis of SM metabolites are 
medRxiv preprint doi: https://doi.org/10.1101/2021.07.16.21260601; this version posted July 20, 2021. The copyright holder for this preprint (which was not certified by peer review) is the author/funder, who has granted medRxiv a license to display the preprint in perpetuity. It is made available under a CC-BY-NC-ND 4.0 International license .

expected. However, the specific association with one particular exit route out of the pathway (via sphingosine and S1P) is striking. Five of the six detected genes (SPTLC3, CERS2, CERS4, SPHK2 and SGPL1) were also found to be significantly linked to $A D$ either through differential gene expression or via genetic associations or both, which suggests that S1P metabolism may be relevant to disease.

S1P is known to be involved in endothelial barrier function in a context-dependent manner. Decreased S1P by lipopolysaccharide (LPS) treatment produced blood brain barrier (BBB) abnormalities, and increased activity of SGPP1 and S1PR 28 . Chronic BBB leakiness is associated with cognitive impairment, but not with signs of brain inflammation ${ }^{29}$. S1P in general increases neuronal and circuit excitability ${ }^{30,31}$. Depletion of the S1P producing enzyme SphK1 induces an impairment of mossy fiber-CA3 LTP and deficits in spatial reference memory ${ }^{32}$. Depletion of SphK2 produced lower levels of hippocampal S1P, reduced histone acetylation and deficits in spatial memory as well as impaired contextual fear extinction ${ }^{33}$. Thus, S1P, SphK1 and SphK2 play specific roles in brain areas serving specific memory functions through intracellular S1P effects as well as signaling pathways downstream of S1P GPCRs. A recent study showed that A $\beta 1-42$ enhanced SphK1 expression and activity after 24 h, but down-regulated them after $96 \mathrm{~h}$ and had no effect on Sphk2. Aß1-42 and SKI II induced free radical formation, disturbed the balance between pro- and anti-apoptotic proteins and evoked cell death in PC12 cells while SP1 rescued part of this damage ${ }^{37}$. S1P may act as a second messenger, but it can also be transported to the extracellular space and may affect cell function via stimulation of the receptors (S1PR1-5). Two modulators of SP1R1 (Fingolimod and SEW2871) have been shown to improve $A \beta$ mediated behavior abnormalities and decrease tau phosphorylation.

To explore the effect of drugs, we used APP/PS1 mice. Fingolimod is a sphingosine-1phosphate receptor modulator approved for treatment of multiple sclerosis in the US. In absence of the drug treatment, we observed that APP/PS1 mice had a significant deficit in the novel object recognition test (NOR) and other array of tests as compared to the WT mice. Upon administration of fingolimod we found that fingolimod-treated APP/PS1 mice 
medRxiv preprint doi: https://doi.org/10.1101/2021.07.16.21260601; this version posted July 20, 2021. The copyright holder for this preprint (which was not certified by peer review) is the author/funder, who has granted medRxiv a license to display the preprint in perpetuity. It is made available under a CC-BY-NC-ND 4.0 International license .

had similar values in NOR-DI as compared to treated WT mice. These results suggested that fingolimod modulated S1P pathway and was able to alleviate cognitive deficits in APP/PS1 mice.

The approach used here opens the possibility of repurposing fingolimod, or other S1P modulators, for treatment of AD. Fingolimod has been shown to modulate both amyloid and tau pathology in $A D$ models ${ }^{55,56,57}$ and it has been proposed to be neuroprotective by modulating S1P signaling in the brain ${ }^{58}$. A recent study used network pharmacology methods and showed the probable pharmacological mechanism of fingolimod in the frontal cortex region of $A D$ patients ${ }^{59}$. Rescuing both memory (synaptic LTP) and the behavior itself (substrate and end-result) with fingolimod is a compelling finding, which provides evidence for dysregulated S1P signaling in AD mice and further supports the identification of this pathway as a high priority candidate AD drug target. The effect of fingolimod in APP/PS1 on behavior and synaptic transmission can be direct or through the activation of S1P receptors or both, since they are not mutually exclusive. We feel fingolimod is likely one of several compounds approved or being tested for other neurodegenerative diseases that can be repurposed. This study integrates diverse types of multi-omics data from $A D$ patients and an animal model to identify multiple, dysregulated steps in SM metabolism. It provides a link between SM dysregulation and changes in brain function. Furthermore, this study suggests that repurposing drugs that target SM metabolic enzymes, such as the S1P receptor, could correct the dysregulation and potentially improve memory and synaptic function.

Thus, using a multi-omics approach to analyze the big data led to the understanding of the sphingolipid pathway and strategies for novel drug discovery in AD. 
medRxiv preprint doi: https://doi.org/10.1101/2021.07.16.21260601; this version posted July 20, 2021. The copyright holder for this preprint (which was not certified by peer review) is the author/funder, who has granted medRxiv a license to display the preprint in perpetuity. It is made available under a CC-BY-NC-ND 4.0 International license .

\section{Methods}

$\underline{\text { Identification of differential gene expression in brain tissue RNA-seq data }}$

We used the reprocessed AMP-AD RNA-seq data available from three studies - the Religious Order Study and the Rush Memory and Aging Project (ROS/MAP), the Mount Sinai Brain Bank cohort (MSBB), and the Mayo clinic RNA-seq study ${ }^{42}$ - covering 7 brain regions (cerebellum, temporal cortex, dorsolateral prefrontal cortex, parahippocampal gyrus, frontal pole, inferior frontal gyrus and superior temporal gyrus), as well as a published meta-analysis of these datasets 42 to identify genes in the SM pathway that are differentially expressed in $A D$ cases compared to controls. Gene expression changes were considered significant at an FDR-corrected $p$-value $\leq 0.05$. All datasets are publicly available, see the Data Availability Statement.

\section{Metabolic networks of brain regions}

Genome-scale metabolic networks of brain regions were reconstructed in our previous study $^{60}$ and we used these metabolic networks for our present work. We integrated the post-mortem brain transcriptome data as mentioned $\mathrm{in}^{60}$. Using iMAT algorithm ${ }^{61}$, we generated context-specific personalized metabolic networks for each post-mortem sample in the dataset. Human cells in general do not proliferate rapidly and they tend to maintain their metabolic functions ${ }^{62}$. We therefore chose the biomass maintenance reaction, glutamate and glutamine exchange as the objective function for the brain regions. We used the dorsolateral prefrontal cortex samples for the present analysis. We performed flux variability analysis (FVA) to evaluate minimum and maximum flux for each reaction in the metabolic networks. If the minimum and maximum flux was 0 then the reactions were considered to be non-active and were assigned a state of 0 , while the remaining reactions were considered to be active and assigned a state of 1 . We carried out the analysis for all context-specific metabolic networks. We generated a matrix of binary values for all reactions in the context-specific metabolic networks. We selected the reactions that were part of sphingolipid metabolism using the subsystem definition. We used Fisher's exact test on the binarized values of reactions to identify reactions with $p$ value of $<0.05$ in $A D$ versus $C N$ samples. These reactions were identified as significant 
medRxiv preprint doi: https://doi.org/10.1101/2021.07.16.21260601; this version posted July 20, 2021. The copyright holder for this preprint (which was not certified by peer review) is the author/funder, who has granted medRxiv a license to display the preprint in perpetuity. It is made available under a CC-BY-NC-ND 4.0 International license .

reactions in the groups. We used COBRA toolbox $v 3.0^{63}$ for metabolic analysis that was implemented in MATLAB R2018a and academic licenses of Gurobi optimizer v7.5 and IBM CPLEX v12.7.1 were used to solve LP and MILP problems.

\section{Neuroimaging processing and analysis}

Participants of the Alzheimer's Disease Neuroimaging Initiative (ADNI) were used in the analysis. Demographic information, imaging scan data, neuropsychological test scores, and clinical information were downloaded from the ADNI data repository (www.loni.usc.edu). As described in detail in previous studies ${ }^{64,65}$, T1-weighted structural magnetic resonance imaging (MRI) scans were processed by using a widely employed automated MRI analysis technique (FreeSurfer) to extract cortical thickness. Preprocessed $\left[{ }^{18} \mathrm{~F}\right]$ FDG positron emission tomography (PET) scans were downloaded. Methods for acquisition and processing of PET scans were described previously (refs). $\left[{ }^{18} \mathrm{~F}\right]$ FDG PET scans were intensity-normalized using a pons region of interest to create standardized uptake value ratio (SUVR) images. For surface-based whole brain analysis of cortical thickness on a vertex-by-vertex basis, the SurfStat software package (www.math.mcgill.ca/keith/surfstat/) was used to perform a multivariable analysis of generalized linear regression to examine the association of genetic variation on brain structural changes. Age, sex, years of education, intracranial volume, and magnetic field strength were used as covariates. In order to adjust for multiple comparisons, the random field theory correction method was used with $p<0.05$ adjusted as the level for significance. For whole brain analysis of brain glucose metabolism on a voxel-wise basis using the processed FDG PET images, SPM12 (www.fil.ion.ucl.ac.uk/spm/) was used to investigate the effect of genetic variation on brain glucose metabolism across the whole brain. Age and sex were used as covariates. In order to adjust for multiple comparisons, the significant statistical parameters were selected to correspond to a threshold of p-value $<0.05$ (FDR-corrected). 
medRxiv preprint doi: https://doi.org/10.1101/2021.07.16.21260601; this version posted July 20, 2021. The copyright holder for this preprint (which was not certified by peer review) is the author/funder, who has granted medRxiv a license to display the preprint in perpetuity. It is made available under a CC-BY-NC-ND 4.0 International license .

For the investigation of SM ratios measured by targeted metabolomics using the Biocrates P180 kit, we used the same cohort data and statistical models used in Toledo et al. ${ }^{19}$. For selection of the most informative SM ratio, we first calculated all ratios between short-chain (chain length $<C 20$ ) and long-chain $(\geq C 20)$ SMs on metabolite levels not adjusted for medication. For each ratio, we then identified significant medications using backward selection based on the Bayesian Information Criterion. Significant medications were included as additional covariates extending the base models described in Toledo et al. ${ }^{19}$ for phenotype associations. Using the $\mathrm{P}_{\text {gain }}$ criterion, which is defined by the ratio of the minimum association p-value of the constituents of a ratio with the association $p$-value of the ratio and provides a measure of significance added by the ratio, we obtained the ratio of SM (d34:1) and SM (d43:1) as the one with the largest overall Pgain.

$\underline{\text { Replication analysis of SM ratios using targeted lipidomics in ADNI-1 }}$

A more detailed lipidomics method was applied in the ADNI-1 samples to obtain better coverage of the sphingolipidome. Methodology on the ADNI cohort was as previously described $^{20}$. In brief, extracted samples were run using reverse phase liquid chromatography coupled with a triple quadrupole mass spectrometer (Agilent 6490, Agilent). Characterization of sphingolipid isomers have been reported previously ${ }^{66}$ where repeated pooled runs using differing mass spectrometry conditions to obtain structurally informative fragments in MS/MS. Ratios were generated using 112 sphingolipid species and log2-transformed. Linear regression with_ADAS-Cog. 13 was done with age, sex, BMI, HDL-C, total cholesterol, clinical triglycerides, fasting status and APOE e4 genotype as covariates. p-values were corrected for multiple correction comparison using the Benjamini and Hochberg approach ${ }^{67}$.

\section{Candidate mGWAS analysis in ADNI-1}

We downloaded genome-wide genotype data for ADNI-1 participants from LONI. Genotype quality control (QC) included exclusion of samples and genotypes with $<95 \%$ call rate and exclusion of variants that violated a Hardy-Weinberg-Equilibrium (HWE) test 
medRxiv preprint doi: https://doi.org/10.1101/2021.07.16.21260601; this version posted July 20, 2021. The copyright holder for this preprint (which was not certified by peer review) is the author/funder, who has granted medRxiv a license to display the preprint in perpetuity. It is made available under a CC-BY-NC-ND 4.0 International license .

p-value of $1 \times 10-5$ or had a minor allele frequency (MAF) $<5 \%$. We then performed autosomal mGWAS analysis with the three SMs (SM (d32:0), SM d(34:1), SM (d38:3)) reported as significantly associated with markers of $A D$ in Toledo et al. ${ }^{19}$, as well as the $\mathrm{SM}(\mathrm{d} 43: 1) / \mathrm{SM}(\mathrm{d} 34: 1)$ ratio reported here. As covariates, we included age, sex, diagnostic group, as well as the first five components derived by multidimensional scaling (MDS) analysis to account for population stratification. The threshold for genome-wide significance adjusted for four metabolic traits was $p$-value $\leq 1.25 \times 10-8$. Genetic associations were calculated using PLINK v1.968.

\section{Phenotype GWAS and global SM mGWAS analysis in ADNI-1/GO/2}

Genome-wide genotyping data of $A D N I-1 / G O / 2$ participants were collected using the Illumina Human 610-Quad, HumanOmni Express, and HumanOmni 2.5M BeadChips. Before imputation, standard QC procedures of GWAS data for genetic markers and subjects were performed (variant call rate $<95 \%$, HWE test p-value $<1 \times 10-6$, and MAF $<1 \%$, participant call rate $<95 \%$, sex check and identity check for related relatives). Then, non-Hispanic Caucasian participants were selected using HapMap 3 genotype data and MDS analysis. Genotype imputation was performed for each genotyping platform separately using the Haplotype Reference Consortium (HRC) reference Panel r1.1 and merged afterwards, resulting in data on 1,576 individuals and 20,779,509 variants. Using this dataset, we ran GWAS analyses for each outcome (A-T-N-C measures, clinical diagnosis and metabolite levels) that included outcome-specific sets of covariates. These are listed in Supplementary Table 6, along with the respective numbers of included individuals and genetic variants.

Annotation of genetic variants and gene-wide significance thresholds 
medRxiv preprint doi: https://doi.org/10.1101/2021.07.16.21260601; this version posted July 20, 2021. The copyright holder for this preprint (which was not certified by peer review) is the author/funder, who has granted medRxiv a license to display the preprint in perpetuity. It is made available under a CC-BY-NC-ND 4.0 International license .

Previously reported metabolite associations for genes in the SM pathway were retrieved from SNiPA ${ }^{50}$, which was also used to identify overlapping expression quantitative trait loci (eQTLs) from multiple sources. Effect directions of genotype-metabolite and eQTL associations were obtained from the original publications ${ }^{50}$. SNiPA was also used to project genetic variants to genes, a process that includes mapping of variants to genes via genomic location, links to genes via expression and protein QTLs, as well as location in a gene-associated promoter or enhancer region 50 . The number of all genetic variants projected to a particular gene was used to derive gene-wise Bonferroni thresholds for significant genetic associations ( $p$-value $\leq 0.05 /$ (number of variants)). Furthermore, as SNPs within genes are correlated due to linkage disequilibrium and Bonferroni correction is often too conservative, we used permutation test, which provides a gene-based empirical p-value that corrects for the number of SNPs within each gene by randomly permuting the phenotypes multi times (20,000 times) and performing statistical tests for all permuted data sets.

\section{Mouse Model}

Experiments were approved by the Division of Comparative Medicine (DCM) from SUNY Downstate Medical Center. APPswe/PS1dE9 (referred to as APP/PS1) and C57BI/6J (referred to as WT) mice were purchased from The Jackson Laboratory. The APP/PS1 is a double transgenic mouse expressing a chimeric mouse/human amyloid precursor protein (Mo/HuAPP695swe) and a mutant human presenilin 1 (PS1-dE9) both directed to CNS neurons ${ }^{69} .50 \%$ of animals used in all experiments were males.

\section{Fingolimod Administration}

To determine if fingolimod oral administration achieves appropriate plasma concentration, we treated 8 WT mice at 7 m.o (50\% Females) with fingolimod at $1 \mathrm{mg} / \mathrm{Kg} / \mathrm{day}$ for 4 wks. Plasma samples were collected at two time points ( $2^{\text {nd }}$ and $4^{\text {th }}$ weeks) after treatment and analyzed by UHPLC and MS-MS. Fingolimod levels in plasma were in $\mathrm{ng} / \mathrm{ml}: 2^{\text {nd }}$ week $=$ $8.03 \pm 0.24$ and $4^{\text {th }}$ week $=10.02 \pm 0.4$. The results indicate that oral administration is an appropriate route for mice experiments. 
medRxiv preprint doi: https://doi.org/10.1101/2021.07.16.21260601; this version posted July 20, 2021. The copyright holder for this preprint (which was not certified by peer review) is the author/funder, who has granted medRxiv a license to display the preprint in perpetuity. It is made available under a CC-BY-NC-ND 4.0 International license .

We used APP/PS1 and their wildtype littermates to examine fingolimod effects in vivo. Fingolimod treatment was provided in drinking water in a dark container and changed every $48 \mathrm{~h}$ to provide $1 \mathrm{mg} / \mathrm{Kg} /$ day.

\section{$\underline{\text { In vitro Electrophysiological recordings }}$}

Mice were anesthetized with Ketamine/Xylazine $(100 / 10 \mathrm{mg} / \mathrm{kg})$ and decapitated with an animal guillotine. Horizontal hippocampal slices $(400 \mu \mathrm{m})$ were prepared using a Vibrotome slicer (VT 1000S; Leica) in ice-cold cutting solution containing the following in mM: 130 potassium gluconate, $5 \mathrm{KCl}, 20$ HEPES acid, 25 glucose, 0.05 kynurenic acid, 0.05 EGTA-K, and pH equilibrated at 7.4 with $\mathrm{KOH}$. After slicing, the tissue was allowed to recover for an hour before the beginning of experiments in artificial CSF (aCSF) that contained the following in mM: $157 \mathrm{Na}^{+}, 136 \mathrm{Cl}^{-}, 2.5 \mathrm{~K}^{+}, 1.6 \mathrm{Mg}^{2+}, 2 \mathrm{Ca}^{2+}, 26 \mathrm{HCO}_{3}^{-}$, and 11 D-glucose.

LTP recordings were performed in an interface chamber (Fine Scientific Tools, Vancouver Canada) and slices were perfused with aCSF continuously bubbled with $95 \% \mathrm{O}_{2} / 5 \% \mathrm{CO}_{2}$, to maintain $\mathrm{pH}$ near 7.4 and the temperature was set at $34^{\circ} \mathrm{C}$. Field excitatory postsynaptic potentials (fEPSPs) were recorded in the CA1 stratum radiatum with a glass electrode filled with aCSF (2-3 M $\Omega$ resistance). The fEPSPs were elicited by stimulating the Schaffer collateral fibers with a bipolar electrode. Input-output curves were obtained, and a stimulus that evoked $\sim 40 \%$ of the maximum fEPSP was selected to record the baseline. Baseline responses were obtained (15 min with an inter-stimulus interval of 20 s) before high-frequency stimulation (HFS) (one train of 100 stimuli at $100 \mathrm{~Hz}$ ) was used to induce synaptic LTP. Responses were recorded for $60 \mathrm{~min}$ after HFS. The tungsten stimulating electrodes were connected to a stimulus isolation unit (Grass S88), and the recordings were made using an Axoclamp 2B amplifier (Molecular Devices) and then filtered $(0.1 \mathrm{~Hz}$ to $10 \mathrm{kHz}$ using $-6 \mathrm{~dB} /$ octave). The voltage signals were digitized and stored on a PC using a DigiData 1200 A (Molecular Devices) for off-line analysis. The fEPSP slope was measured and expressed as a percentage of baseline. The data was analyzed using Axon ${ }^{\mathrm{TM}}$ pCLAMP ${ }^{\mathrm{TM}}$ software, and the results are expressed as the mean \pm 
medRxiv preprint doi: https://doi.org/10.1101/2021.07.16.21260601; this version posted July 20, 2021. The copyright holder for this preprint (which was not certified by peer review) is the author/funder, who has granted medRxiv a license to display the preprint in perpetuity. It is made available under a CC-BY-NC-ND 4.0 International license .

standard error of the mean (SEM). Data was analyzed statistically using repeated measures ANOVA with the SPSS package.

\section{Novel Object Recognition (NOR)}

Mice were habituated to experimental apparatus consisting of a gray rectangular open field $(60 \mathrm{~cm} \times 50 \mathrm{~cm} \times 26 \mathrm{~cm}$ ) for $5 \mathrm{~min}$ in the absence of any objects for 3 days. On the third day, after the habituation trial, mice were placed in the experimental apparatus in the presence of two identical objects and allowed to explore them for $5 \mathrm{~min}$. After a retention interval of $24 \mathrm{~h}$, mice were placed again in the apparatus, where one of the objects was replaced by a novel object. All sessions were recorded using Noldus Media Recorder software. Exploration of the objects was defined as the mice facing and sniffing the objects within $2 \mathrm{~cm}$ distance and/or touching them, assessed with ANY-maze software. The ability of the mouse to recognize the novel object (discrimination index) was determined by dividing the mean time exploring the novel object by the mean of the total time exploring the novel and familiar objects during the test session.

\section{Barnes Maze}

The behavioral apparatus consisted of a white flat, circular disk with 20 holes around its perimeter. One hole held the entrance to a darkened escape box not visible from the surface of the board, allowing the subject to exit the maze. The escape chamber position remained fixed during all trials. Mice learn the location of the escape hole using spatial reference points that were fixed in relation to the maze (extra-maze cues). The task consisted of one habituation trial on day 1 where the escape hole was presented to the animal, the animal remained in the escape box for 2 min. After the habituation trial the training phase consisted of four 3-min trials of spatial acquisition for 4 consecutive days with a 15 min inter-trial interval. On the fifth day (probe trial) the escape box was removed, and the animals were allowed to explore the maze for $90 \mathrm{~s}$. All sessions were recorded using Debut video software, and assessed through ANY-maze software. For each trial, several parameters were recorded to assess performance. These include: the latency to locate the escape box, the number of incorrect holes checked prior to entering the escape box, as well as the distance traveled prior to locating the escape box. For the probe trial, 
medRxiv preprint doi: https://doi.org/10.1101/2021.07.16.21260601; this version posted July 20, 2021. The copyright holder for this preprint

(which was not certified by peer review) is the author/funder, who has granted medRxiv a license to display the preprint in perpetuity. It is made available under a CC-BY-NC-ND 4.0 International license .

time spent in the target quadrant and target hole were analyzed.

\section{Data Availability}

Metabolomics datasets from the AbsoluteIDQ-p180 metabolomics kit used in the current analyses for the ADNI-1 and ADNI-GO/-2 cohorts as well as the RNASeq data from the ROS/MAP, Mount Sinai Brain Bank Cohort, and the Mayo Clinic cohort are available via the Accelerating Medicines Partnership-Alzheimer's Disease (AMP-AD) Knowledge Portal and can be accessed at http://dx.doi.org/10.7303/syn5592519 (ADNI-1), http://dx.doi.org/10.7303/syn9705278 (ADNI-GO/-2), https://doi.org/10.7303/syn3388564 (ROS/MAP), https://doi.org/10.7303/syn3157743 (MSSB), and https://doi.org/10.7303/syn5550404 (Mayo clinic). The full complement of clinical and demographic data for the ADNI cohorts are hosted on the LONI data sharing platform and can be requested at http://adni.loni.usc.edu/data-samples/accessdata/. The full complement of clinical and demographic data for the ROS/MAP cohorts are available via the Rush AD Center Resource Sharing Hub and can be requested at https://www.radc.rush.edu.

\section{Acknowledgements}

Data collection and sharing for this project was funded by the Alzheimer's Disease Neuroimaging Initiative (ADNI) (National Institutes of Health Grant U01 AG024904) and DOD ADNI (Department of Defense award number W81XWH-12-2-0012). ADNI is funded by the National Institute on Aging, the National Institute of Biomedical Imaging and Bioengineering, and through generous contributions from the following: AbbVie, Alzheimer's Association; Alzheimer's Drug Discovery Foundation; Araclon Biotech; BioClinica, Inc.; Biogen; Bristol-Myers Squibb Company; CereSpir, Inc.; Cogstate; Eisai Inc.; Elan Pharmaceuticals, Inc.; Eli Lilly and Company; Eurolmmun; F. Hoffmann-La Roche Ltd and its affiliated company Genentech, Inc.; Fujirebio; GE Healthcare; IXICO Ltd.; Janssen Alzheimer Immunotherapy Research \& Development, LLC.; Johnson \& Johnson Pharmaceutical Research \& Development LLC.; Lumosity; Lundbeck; Merck \& Co., Inc.; Meso Scale Diagnostics, LLC.; NeuroRx Research; Neurotrack Technologies; Novartis Pharmaceuticals Corporation; Pfizer Inc.; Piramal Imaging; Servier; Takeda Pharmaceutical Company; and Transition Therapeutics. The Canadian Institutes of Health Research is providing funds to support ADNI clinical sites in Canada. Private sector contributions are facilitated by the Foundation for the National Institutes of Health (www.fnih.org). The grantee organization is the Northern California Institute for Research 
medRxiv preprint doi: https://doi.org/10.1101/2021.07.16.21260601; this version posted July 20, 2021. The copyright holder for this preprint (which was not certified by peer review) is the author/funder, who has granted medRxiv a license to display the preprint in perpetuity. It is made available under a CC-BY-NC-ND 4.0 International license .

and Education, and the study is coordinated by the Alzheimer's Therapeutic Research Institute at the University of Southern California. ADNI data are disseminated by the Laboratory for Neuro Imaging at the University of Southern California.

The Religious Orders and the Rush Memory and Aging studies were supported by the National Institute on Aging grants P30AG10161, R01AG15819, R01AG17917, U01AG46152, and U01AG61356. National Institute on Aging (NIA) supported this work (R01 AG059093). NIA also supported the Alzheimer Disease Metabolomics Consortium which is a part of NIA's national initiatives AMP-AD and M²OVE-AD (R01 AG046171, RF1 AG051550, 3U01 AG061359-02S1, and 3U01 AG024904-09S4). Additionally, M.A., R.K.D., and G.K. are supported by NIA grants RF1 AG058942 and R01 AG057452. M.A. and G.K. are also supported by funding from Qatar National Research Fund NPRP8-0613-011. K.N. is supported by NIH grants NLM R01 LM012535 and NIA R03 AG054936. X.H. is supported by NIA grant RF1 AG061872. P.B. acknowledges the support of 5 U01 AG061359-02 and 5U01 AG061359-03 from NIA. C.F. acknowledges the support of R01AG062514, U01AG046139 from NIA.

\section{Figure legends:}

Figure 1: Overview of sphingolipid pathway manually curated from the Recon3D model. The metabolites participating in reactions are represented in boxes. The arrows for reactions A-K are colored based on the direction in the pathway. Some reactions are not reversible (single arrows). The table on the right lists the catalyzing enzymes in the sphingolipid pathway in humans and are denoted with the same color code as the reaction arrow.

Figure 2: Box plot of reaction fluxes for (a) serine palmitoyl transferase, (b) sphingomyelin synthase, and (c) ceramide kinase reactions. The orange, green, blue and purple bars correspond to $\mathrm{AD}, \mathrm{MCl}, \mathrm{NCl}$ and other dementia.

Figure 3: Association of genetic variants in SPTLC3 and SGMS1 with structural (MRI) and molecular (FDG-PET) neuroimaging phenotypes. A) Gene-based association analysis of SPTLC3 with cognitive performance (Rey auditory verbal learning test total score). D) Gene-based association analysis of SGMS1 with global brain glucose metabolism. B \& E) Surface-based whole brain analysis of cortical thickness (brain atrophy measured from MRI scans) for SPTLC3 and SGMS1. C \& F) Voxel-based whole brain analysis of brain glucose metabolism measured from FDG PET scans for SPTLC3 and SGMS1.

Figure 4: Hybrid network of genetic associations revealed by gene-based association studies and significant partial correlations of detected sphingomyelins ${ }^{8,19}$. The six identified genes can be grouped into two categories: global sphingomyelin synthesis and synthesis and degradation of sphingosine-1-phosphate. The selected SM ratio is colored in orange, other SM species are in 
medRxiv preprint doi: https://doi.org/10.1101/2021.07.16.21260601; this version posted July 20, 2021. The copyright holder for this preprint (which was not certified by peer review) is the author/funder, who has granted medRxiv a license to display the preprint in perpetuity. It is made available under a CC-BY-NC-ND 4.0 International license .

green (light green: non-targeted metabolomics in Shin et al. ${ }^{8}$; dark green: targeted metabolomics in ADNI and Draisma et al. ${ }^{6}$ ), and genes are in dark yellow.

Figure 5. APP/PS1 mice hippocampal dependent behavior and synaptic transmission assessment and effect of fingolimod treatment.

A. Exploration time spent on the novel object in the NOR test session. Data is expressed as a discrimination index \pm SEM. B. Barnes maze performance during training days. Acquisition learning trials were performed, and the time it took to locate and enter into the escape box was reported in seconds. The average performance of four trials per day was expressed as mean \pm SEM. A shorter latency indicates faster spatial learning. C. Probe trial was performed on day 5 of the Barnes Maze protocol, during which the escape box was removed. The percentage of time spent inside the target quadrant (the previous escape box location) is plotted \pm SEM. A larger percentage of time indicates better spatial memory. D. LTP timeline. Plotted are normalized evoked excitatory post-synaptic potentials (EPSPs) slopes (Y) vs. recording time (X). The first 20 min of evoked responses were normalized and used as the baseline responses of LTP. E. Representative analog traces of evoked EPSPs before (light purple and grey) and after (blue and green) high frequency stimulation (HFS). F. The magnitude of LTP was determined according to the responses between 45 and 60 min after the HFS. Data represent mean fEPSP Slope \pm SEM. ( $n=6$ mice in each group). G. APP/PS1 mice treated with fingolimod were tested in NOR task. Data is expressed as a discrimination index \pm SEM. Fingolimod treatment significantly enhance the discrimination index of the APP/PS1 mice. H. Average performance of four trials per day expressed as mean \pm SEM and I. Percentage of time spent inside the target quadrant \pm SEM at the Barnes Maze task of APP/PS1 fingolimod treated mice. Fingolimod mitigated the spatial learning deficits of the APP/PS1 at 9 mo. J. LTP of the CA3 to CA1 synapse timeline. $\mathbf{K}$. Representative analog traces of evoked EPSPs before (light blue and light red) and after (blue and red) HFS. L. The APP/PS1 treated mice group significantly augmented the normalized slope of fEPSP after HFS.

Figure 6: Overview of the study. We used information obtained from (a) post-mortem brain transcriptomics analysis; (b) metabolic networks of brain regions; (c) genetic variants associated with AD biomarkers including neuroimaging endophenotypes (MRI and FDG PET); (d) plasma metabolomics and lipidomics analysis; (e) genetic screening using SM (d43:1)/SM (d34:1) ratio. The balance of ceramide and sphingomyelin levels in $A D$ could be maintained by modulating S1PR activity. The hypothesis was tested on APP/PS1 mice treated with fingolimod. 
medRxiv preprint doi: https://doi.org/10.1101/2021.07.16.21260601; this version posted July 20, 2021. The copyright holder for this preprint (which was not certified by peer review) is the author/funder, who has granted medRxiv a license to display the preprint in perpetuity. It is made available under a CC-BY-NC-ND 4.0 International license .

\section{Supplementary files}

Supplementary Table 1: List of enzymes in the SM pathway. The list of enzymes was curated from human genome-scale metabolic reconstruction, Recon 3D.

Supplementary Table 2: Differential expression for genes in the SM pathway. The expression changes were analyzed from post-mortem brain samples and compared in $A D$ vs controls.

Supplementary Table 3: Genetic variants in the coding regions of genes in SM pathway associated with $\mathrm{AD}$ and A-T-N-C measures. Gene-based association analysis pof ADNI individuals were used for identifying the genetic variants.

Supplementary Table 4: Sphingolipids profiled in ADNI1 individuals. A total of 112 individual species and 12,544 ratios were identified from the comprehensive lipidomics analysis.

Supplementary Table 5: Genome-wide and gene-wide significant associations for 14 related SMs for six genes in the pathway.

Supplementary Table 6: GWAS analyses for A-T-N-C measures, clinical diagnosis and metabolites levels in 1,576 individuals

Supplementary Figure 1: Association of genetic variants in CERS3 with CSF t-tau biomarker

Supplementary Figure 2: Latency analysis in Fingolimod treated vs untreated APP/PS1 mice. Comparison of APP/PS1 Fingolimod treated vs. untreated APP/PS1 (9 m.o. $50 \% n=6$ treated, 4 untreated), analysis of the latency during training shows a deficit in APP/PS1 untreated compared to APP/PS1 treated s (RM-ANOVA F= 3.1; $=$ 0.041)

\section{References}

1. Anderson, R. M., Hadjichrysanthou, C., Evans, S. \& Wong, M. M. Why do so many clinical trials of therapies for Alzheimer's disease fail? Lancet 390, (2017).

2. Huang, L.-K., Chao, S.-P. \& Hu, C.-J. Clinical trials of new drugs for Alzheimer disease. Journal of Biomedical Science vol. 27 (2020).

3. Grimm, M. O. W., Tschäpe, J.-A., Grimm, H. S., Zinser, E. G. \& Hartmann, T. Altered membrane fluidity and lipid raft composition in presenilin-deficient cells. Acta Neurol. 
medRxiv preprint doi: https://doi.org/10.1101/2021.07.16.21260601; this version posted July 20, 2021. The copyright holder for this preprint

(which was not certified by peer review) is the author/funder, who has granted medRxiv a license to display the preprint in perpetuity.

It is made available under a CC-BY-NC-ND 4.0 International license .

Scand. Suppl. 185, 27-32 (2006).

4. Kunkle, B. W. et al. Genetic meta-analysis of diagnosed Alzheimer's disease identifies new risk loci and implicates $A \beta$, tau, immunity and lipid processing. Nat. Genet. 51, 414-430 (2019).

5. Sienski, G. et al. disrupts intracellular lipid homeostasis in human iPSC-derived glia. Sci. Transl. Med. 13, (2021).

6. Draisma, H. H. M. et al. Genome-wide association study identifies novel genetic variants contributing to variation in blood metabolite levels. Nat. Commun. 6, 7208 (2015).

7. Lotta, L. A. et al. Cross-platform genetic discovery of small molecule products of metabolism and application to clinical outcomes. doi:10.1101/2020.02.03.932541.

8. Shin, S.-Y. et al. An atlas of genetic influences on human blood metabolites. Nat. Genet. 46, 543-550 (2014).

9. Farley, S. Linking lipids to Alzheimer's. Nat. Rev. Drug Discov. 3, 300-300 (2004).

10. Zhu, T.-B. et al. Lipid metabolism in Alzheimer's disease. Brain Res. Bull. 144, 68-74 (2019).

11. Zarrouk, A. et al. Lipid Biomarkers in Alzheimer's Disease. Curr. Alzheimer Res. 15, 303312 (2018).

12. Bruce, K. D., Zsombok, A. \& Eckel, R. H. Lipid Processing in the Brain: A Key Regulator of Systemic Metabolism. Front. Endocrinol. 8, 60 (2017).

13. Alessenko, A. V. \& Albi, E. Exploring Sphingolipid Implications in Neurodegeneration. Front. Neurol. 11, 437 (2020).

14. Grassi, S. et al. Lipid rafts and neurodegeneration: structural and functional roles in physiologic aging and neurodegenerative diseases. J. Lipid Res. 61, 636-654 (2020).

15. Han, X., Cheng, H., Fryer, J. D., Fagan, A. M. \& Holtzman, D. M. Novel role for apolipoprotein E in the central nervous system. Modulation of sulfatide content. J. Biol. Chem. 278, 8043-8051 (2003). 
medRxiv preprint doi: https://doi.org/10.1101/2021.07.16.21260601; this version posted July 20, 2021. The copyright holder for this preprint (which was not certified by peer review) is the author/funder, who has granted medRxiv a license to display the preprint in perpetuity. It is made available under a CC-BY-NC-ND 4.0 International license .

16. Schneider, N. et al. Sphingomyelin in Brain and Cognitive Development: Preliminary Data. eNeuro 6, (2019).

17. Han, X. Multi-dimensional mass spectrometry-based shotgun lipidomics and the altered lipids at the mild cognitive impairment stage of Alzheimer's disease. Biochimica et Biophysica Acta (BBA) - Molecular and Cell Biology of Lipids vol. 1801 774-783 (2010).

18. Han, X. et al. Metabolomics in Early Alzheimer's Disease: Identification of Altered Plasma Sphingolipidome Using Shotgun Lipidomics. PLoS ONE vol. 6 e21643 (2011).

19. Toledo, J. B. et al. Metabolic network failures in Alzheimer's disease: A biochemical road map. Alzheimers. Dement. 13, 965-984 (2017).

20. Huynh, K. et al. Concordant peripheral lipidome signatures in two large clinical studies of Alzheimer's disease. Nature Communications vol. 11 (2020).

21. Allen, M. et al. Conserved brain myelination networks are altered in Alzheimer's and other neurodegenerative diseases. Alzheimers. Dement. 14, 352-366 (2018).

22. Liu, Q. \& Zhang, J. Lipid metabolism in Alzheimer's disease. Neurosci. Bull. 30, 331-345 (2014).

23. Green, D. R. Apoptosis and sphingomyelin hydrolysis. The flip side. The Journal of cell biology vol. 150 F5-7 (2000).

24. Cutler, R. G. et al. Involvement of oxidative stress-induced abnormalities in ceramide and cholesterol metabolism in brain aging and Alzheimer's disease. Proc. Natl. Acad. Sci. U. S. A. 101, 2070-2075 (2004).

25. Grimm, M. O. W. et al. Regulation of cholesterol and sphingomyelin metabolism by amyloid-beta and presenilin. Nat. Cell Biol. 7, 1118-1123 (2005).

26. Tanabe, F., Nakajima, T. \& Ito, M. The thiol proteinase inhibitor E-64-d ameliorates amyloid- $\beta$-induced reduction of SAPPa secretion by reversing ceramide-induced protein kinase C down-regulation in SH-SY5Y neuroblastoma cells. Biochem. Biophys. Res. Commun. 441, 256-261 (2013). 
medRxiv preprint doi: https://doi.org/10.1101/2021.07.16.21260601; this version posted July 20, 2021. The copyright holder for this preprint

(which was not certified by peer review) is the author/funder, who has granted medRxiv a license to display the preprint in perpetuity.

It is made available under a CC-BY-NC-ND 4.0 International license .

27. Puglielli, L., Ellis, B. C., Saunders, A. J. \& Kovacs, D. M. Ceramide Stabilizes $\beta$-Site Amyloid Precursor Protein-cleaving Enzyme 1 and Promotes Amyloid $\beta$-Peptide Biogenesis. Journal of Biological Chemistry vol. 278 19777-19783 (2003).

28. Malaplate-Armand, C. et al. Soluble oligomers of amyloid- $\beta$ peptide induce neuronal apoptosis by activating a cPLA2-dependent sphingomyelinase-ceramide pathway. Neurobiology of Disease vol. 23 178-189 (2006).

29. Jesko, H., Okada, T., Strosznajder, R. P. \& Nakamura, S.-I. Sphingosine kinases modulate the secretion of amyloid $\beta$ precursor protein from SH-SY5Y neuroblastoma cells: the role of a-synuclein. Folia Neuropathol. 52, 70-78 (2014).

30. Hammond, T. R., Robinton, D. \& Stevens, B. Microglia and the Brain: Complementary Partners in Development and Disease. Annu. Rev. Cell Dev. Biol. 34, 523-544 (2018).

31. Sakai, J. Core Concept: How synaptic pruning shapes neural wiring during development and, possibly, in disease. Proc. Natl. Acad. Sci. U. S. A. 117, 16096-16099 (2020).

32. Safaiyan, S. et al. Age-related myelin degradation burdens the clearance function of microglia during aging. Nat. Neurosci. 19, 995-998 (2016).

33. Takahashi, K., Rochford, C. D. P. \& Neumann, H. Clearance of apoptotic neurons without inflammation by microglial triggering receptor expressed on myeloid cells-2. J. Exp. Med. 201, 647-657 (2005).

34. Nugent, A. A. et al. TREM2 Regulates Microglial Cholesterol Metabolism upon Chronic Phagocytic Challenge. Neuron 105, 837-854.e9 (2020).

35. Olah, M. et al. Single cell RNA sequencing of human microglia uncovers a subset associated with Alzheimer's disease. Nat. Commun. 11, 6129 (2020).

36. Srinivasan, K. et al. Alzheimer's Patient Microglia Exhibit Enhanced Aging and Unique Transcriptional Activation. Cell Rep. 31, 107843 (2020).

37. Friedman, B. A. et al. Diverse Brain Myeloid Expression Profiles Reveal Distinct Microglial Activation States and Aspects of Alzheimer's Disease Not Evident in Mouse Models. Cell 
medRxiv preprint doi: https://doi.org/10.1101/2021.07.16.21260601; this version posted July 20, 2021. The copyright holder for this preprint

(which was not certified by peer review) is the author/funder, who has granted medRxiv a license to display the preprint in perpetuity.

It is made available under a CC-BY-NC-ND 4.0 International license .

Rep. 22, 832-847 (2018).

38. Hammond, T. R. et al. Single-Cell RNA Sequencing of Microglia throughout the Mouse Lifespan and in the Injured Brain Reveals Complex Cell-State Changes. Immunity 50, 253271.e6 (2019).

39. Keren-Shaul, H. et al. A Unique Microglia Type Associated with Restricting Development of Alzheimer's Disease. Cell 169, 1276-1290.e17 (2017).

40. Mathys, H. et al. Temporal Tracking of Microglia Activation in Neurodegeneration at SingleCell Resolution. Cell Rep. 21, 366-380 (2017).

41. Mrdjen, D. et al. High-Dimensional Single-Cell Mapping of Central Nervous System Immune Cells Reveals Distinct Myeloid Subsets in Health, Aging, and Disease. Immunity 48, 380-395.e6 (2018).

42. Wan, Y.-W. et al. Meta-Analysis of the Alzheimer's Disease Human Brain Transcriptome and Functional Dissection in Mouse Models. Cell Rep. 32, 107908 (2020).

43. Brunk, E. et al. Recon3D enables a three-dimensional view of gene variation in human metabolism. Nat. Biotechnol. 36, 272-281 (2018).

44. Baloni, P. et al. Metabolic Network Analysis Reveals Altered Bile Acid Synthesis and Cholesterol Metabolism in Alzheimer's Disease. SSRN Electronic Journal doi:10.2139/ssrn.3596216.

45. Jack, C. R., Jr et al. NIA-AA Research Framework: Toward a biological definition of Alzheimer's disease. Alzheimers. Dement. 14, 535-562 (2018).

46. Beecham, G. W. et al. Genome-wide association meta-analysis of neuropathologic features of Alzheimer's disease and related dementias. PLoS Genet. 10, e1004606 (2014).

47. Illig, T. et al. A genome-wide perspective of genetic variation in human metabolism. Nat. Genet. 42, 137-141 (2009).

48. Davatzikos, C., Xu, F., An, Y., Fan, Y. \& Resnick, S. M. Longitudinal progression of Alzheimer's-like patterns of atrophy in normal older adults: the SPARE-AD index. Brain 
medRxiv preprint doi: https://doi.org/10.1101/2021.07.16.21260601; this version posted July 20, 2021. The copyright holder for this preprint

(which was not certified by peer review) is the author/funder, who has granted medRxiv a license to display the preprint in perpetuity.

It is made available under a CC-BY-NC-ND 4.0 International license .

132, 2026-2035 (2009).

49. Mohs, R. C. et al. Development of cognitive instruments for use in clinical trials of antidementia drugs: additions to the Alzheimer's Disease Assessment Scale that broaden its scope. The Alzheimer's Disease Cooperative Study. Alzheimer Dis. Assoc. Disord. 11 Suppl 2, S13-21 (1997).

50. Arnold, M., Raffler, J., Pfeufer, A., Suhre, K. \& Kastenmüller, G. SNiPA: an interactive, genetic variant-centered annotation browser. Bioinformatics 31, 1334-1336 (2015).

51. Vasiliou, S. Oral fingolimod for the treatment of relapsing-remitting multiple sclerosis. Drugs of Today vol. 46315 (2010).

52. Lok, K. et al. Characterization of the APP/PS1 mouse model of Alzheimer's disease in senescence accelerated background. Neurosci. Lett. 557 Pt B, 84-89 (2013).

53. Sanchez, T. et al. Phosphorylation and action of the immunomodulator FTY720 inhibits vascular endothelial cell growth factor-induced vascular permeability. J. Biol. Chem. 278, 47281-47290 (2003).

54. Paugh, S. W., Payne, S. G., Barbour, S. E., Milstien, S. \& Spiegel, S. The immunosuppressant FTY720 is phosphorylated by sphingosine kinase type 2. FEBS Lett. 554, 189-193 (2003).

55. Jęśko, H., Wencel, P. L., Lukiw, W. J. \& Strosznajder, R. P. Modulatory Effects of Fingolimod (FTY720) on the Expression of Sphingolipid Metabolism-Related Genes in an Animal Model of Alzheimer's Disease. Mol. Neurobiol. 56, 174-185 (2019).

56. Angelopoulou, E. \& Piperi, C. Beneficial Effects of Fingolimod in Alzheimer's Disease: Molecular Mechanisms and Therapeutic Potential. Neuromolecular Med. 21, 227-238 (2019).

57. Carreras, I. et al. Dual dose-dependent effects of fingolimod in a mouse model of Alzheimer's disease. Sci. Rep. 9, 10972 (2019).

58. Groves, A., Kihara, Y. \& Chun, J. Fingolimod: direct CNS effects of sphingosine 1- 
medRxiv preprint doi: https://doi.org/10.1101/2021.07.16.21260601; this version posted July 20, 2021. The copyright holder for this preprint

(which was not certified by peer review) is the author/funder, who has granted medRxiv a license to display the preprint in perpetuity.

It is made available under a CC-BY-NC-ND 4.0 International license .

phosphate $(\mathrm{S} 1 \mathrm{P})$ receptor modulation and implications in multiple sclerosis therapy. $\mathrm{J}$. Neurol. Sci. 328, 9-18 (2013).

59. Yin, P., Xue, Y., Wang, T., Zhong, D. \& Li, G. The Therapeutic Targets of Fingolimod (FTY720) Are Involved in Pathological Processes in the Frontal Cortex of Alzheimer's Disease Patients: A Network Pharmacology Study. Front. Aging Neurosci. 13, 609679 (2021).

60. Baloni, P. et al. Metabolic Network Analysis Reveals Altered Bile Acid Synthesis and Metabolism in Alzheimer's Disease. Cell Rep Med 1, 100138 (2020).

61. Zur, H., Ruppin, E. \& Shlomi, T. iMAT: an integrative metabolic analysis tool. Bioinformatics 26, 3140-3142 (2010).

62. Agren, R. et al. Reconstruction of genome-scale active metabolic networks for 69 human cell types and 16 cancer types using INIT. PLoS Comput. Biol. 8, e1002518 (2012).

63. Heirendt, L. et al. Creation and analysis of biochemical constraint-based models using the COBRA Toolbox v.3.0. Nat. Protoc. 14, 639-702 (2019).

64. Nho, K. et al. Association of Altered Liver Enzymes With Alzheimer Disease Diagnosis, Cognition, Neuroimaging Measures, and Cerebrospinal Fluid Biomarkers. JAMA Netw Open 2, e197978 (2019).

65. Nho, K. et al. Altered bile acid profile in mild cognitive impairment and Alzheimer's disease: Relationship to neuroimaging and CSF biomarkers. Alzheimers. Dement. 15, 232-244 (2019).

66. Huynh, K. et al. High-Throughput Plasma Lipidomics: Detailed Mapping of the Associations with Cardiometabolic Risk Factors. Cell Chem Biol 26, 71-84.e4 (2019).

67. Benjamini, Y. \& Hochberg, Y. Controlling the False Discovery Rate: A Practical and Powerful Approach to Multiple Testing. Journal of the Royal Statistical Society: Series B (Methodological) vol. 57 289-300 (1995).

68. Chang, C. C. et al. Second-generation PLINK: rising to the challenge of larger and richer 
medRxiv preprint doi: https://doi.org/10.1101/2021.07.16.21260601; this version posted July 20, 2021. The copyright holder for this preprint (which was not certified by peer review) is the author/funder, who has granted medRxiv a license to display the preprint in perpetuity. It is made available under a CC-BY-NC-ND 4.0 International license .

datasets. Gigascience 4, 7 (2015).

69. Jankowsky, J. L. et al. Mutant presenilins specifically elevate the levels of the 42 residue beta-amyloid peptide in vivo: evidence for augmentation of a 42-specific gamma secretase.

Hum. Mol. Genet. 13, 159-170 (2004). 